\title{
A CONFORMAÇÃO CONSTITUCIONAL DO NOVO REGIME BRASILEIRO DE TRIBUTAÇÃO OFFSHORE: UM ESTUDO DA LEI N. 12.973/2014
}

\author{
THE CONSTITUTIONAL FRAMEWORK OF THE NEW BRAZILIAN OFFSHORE TAX ORDER: A
}

STUDY OF FEDERAL LAW NO. 12,973 OF 2014

Brenno Birckholz da Silva*

\begin{abstract}
Resumo:
A recém-aprovada sistemática de $C F C$ rules brasileira suscita duas importantes indagações: (i) a nova legislação é (ou não) conforme aos princípios econômicos do texto constitucional?; e (ii) quais os efeitos desse regramento na internacionalização produtiva de empresas nacionais, bem como sobre a competitividade de pessoas jurídicas controladas e/ou coligadas àquelas? O objetivo final é a aferição de possível relação de causalidade entre a tributação adotada pelo país e sua potencial contribuição ao desenvolvimento econômico-produtivo nacional, sem prejuízo do interesse orçamentário e de coibir a evasão fiscal. Tomadas essas premissas, o grande desafio orienta-se à construção de um ponto ótimo de inflexão tributária, elaborando uma norma world wide income taxation que proteja a arrecadação, mas que ao mesmo tempo não inviabilize as empresas brasileiras de competir no mercado internacional globalizado.
\end{abstract}

Palavras-chave: Direito Tributário Internacional. Tributação do lucro de Controladas e Coligadas no exterior. Política tributária e desenvolvimento econômico. Constitucionalidade da Lei n. $12.973 / 2014$

\begin{abstract}
:
The recently enacted Brazilian CFC rules encompasses two major questions: (i) has the new legislation passed under the framework of the economic principles of the constitutional text?; and (ii) Which effects do arise, regarding the internationalization of Brazilian enterprises' production chains, as well as their competitiveness and their corporate subsidiaries' and/or affiliates', as well? The ultimate goal is scouting for possible cause and effect relation between taxation adopted by the country and its potential contribution to economic and productive development, notwithstanding the scope of revenue collection and curbing premeditated tax evasion conduits. Taken these assumptions, the great challenge consists of drafting an optimal point of taxation, upheld by a standard worldwide income taxation in order to protect national collection, but at the same time not hindering the Brazilian companies of competing in the globalized international market.
\end{abstract}

Keywords: International Tax Law, CFC rules. Tax policy and economic development. Constitutionality of Federal Law No. 12,973 of 2014.

\footnotetext{
Mestre em Droit - Gestion du Patrimoine Privé pela Université Montesquieu - Bordeaux IV (França) como bolsista da União Europeia de Excelência Acadêmica, Bacharel em Direito pela Universidade de São Paulo e Jovem Jurista do ano de 2014 pelo Banco Santander e pela Universidade de São Paulo com a Tese de Láurea Tributação da Renda Auferida no Exterior e as Controlled Foreign Corporations - Limites do Planejamento Tributário Internacional, classificada entre os melhores trabalhos jurídicos do ano de 2013.
} 


\section{As CFC rules e o novo contexto econômico mundial}

A reconfiguração da geopolítica mundial associa-se à intensificação da circulação de bens, recursos e tecnologias, ao progresso das telecomunicações e ao câmbio intenso de informações no âmbito entre-países. Trata-se de nova fase na evolução capitalista, característica do Homo globalizatus. Samir Amin, ${ }^{1}$ ao apontar uma inovação no aprofundamento das relações vinculantes entre países, ressalta "a separação entre o espaço globalizado da gestão econômica do capitalismo e os espaços nacionais de sua gestão política e social". De fato, a complexificação das transações econômicas, a internacionalização de cadeias produtivas $^{2}$ e um mercado consumidor relativamente universal modificaram substancialmente o cenário econômico, sobretudo nas últimas décadas, trazendo em si implicações que se espraiam também no âmbito dos ordenamentos jurídicos, especialmente no que tange ao regime de tributação incidente sobre tais operações transnacionais.

Insertas no contexto de crescente importância do mercado externo e das trocas comerciais mundiais, as empresas brasileiras prospectam novos mercados para além da fronteira nacional, reorientando o locus da participação brasileira na economia mundial. Usualmente considerado importador de capitais (receptor de investimentos), o país vem demonstrando acréscimos sucessivos do Investimento Brasileiro Direto ${ }^{3}$ (IBD), com o consequente aumento da importância do investimento no exterior para a economia brasileira. $^{4}$

Compreende-se, nesse contexto, um inter-relacionamento significativo entre o direito e o fenômeno econômico, em especial pela atual conjuntura econômica global e massificada. Nesse ínterim, Marcel Merle ${ }^{5}$ aponta como elementos caracterizadores do sistema internacional contemporâneo:

\footnotetext{
AMIN, Samir. Transforming the world economy: nine critical essays on the new international economic order. Kent: United Nations University \& Hodder and Stoughton, 1984.

2 CASELlA, Paulo B. União Européia - instituições e ordenamento jurídico. 5. ed. São Paulo: LTr, 2002.

3 A projeção para o IBD em 2012 é de R $\$ 5$ bilhões, invertendo o saldo negativo de R \$9,3 bilhões do ano de 2011, conforme dados da Revista Exame online. Disponível em: <http://exame.abril.com.br/negocios/ empresas/noticias/multinacionais-do-brasil-voltarao-a-investir-no-exterior-3>. Acesso em: 3 abr. 2013.

4 Segundo estudo conjunto SOBEET (Sociedade Brasileira de Estudos de Empresas Transnacionais e da Globalização Econômica) e Valor Econômico realizado em 2011, mais de 80\% das 51 grandes empresas entrevistadas afirma que a tendência do investimento na transnacionalização produtiva é manter-se inalterada ou crescer até $30 \%$. Disponível em:

$<$ http://www.fiesp.com.br/irs/coscex/pdf/transparencias_reuniao_coscex_20_03_12_luis_afonso_lima_ sobeet.pdf $>$. Acesso em: 2 abr. 2012.

5 MERLE, Marcel. Sociología de las relaciones internacionales. Trad. Mesa Garrido. 2. ed. Madrid: Alianza Universidad, 1980. p. 399 e ss.
} 
i) a intensificação das trocas econômicas, conformadas num mercado de proporções mundiais;

ii) a densificação da rede de organizações internacionais, universais e regionais;

iii) aceleração da rapidez e volume de comunicações e deslocamento de pessoas;

iv) transmissão de informações em tempo instantâneo;

v) campo estratégico unificado, em âmbito mundial.

Especialmente a partir da década de 90, os instrumentos tradicionais de combate à fraude e à sonegação fiscal não mais eram suficientes para conter o deficit arrecadatório. Isto, porque o tratamento legislativo endossava a transferência de lucros para entidades situadas nos paraísos fiscais ${ }^{6}$ (tax havens) ou em países de tributação normal que aplicassem um regime preferencial, ${ }^{7}$ procrastinando ad eternum o critério temporal da hipótese de incidência (tax deferral), pelo simples fato de que a distribuição de dividendos seria sempre diferida.

A alternativa utilizada pelos países de carga tributária regular, como medida de neutralização desse planejamento tributário, foi transplantar o regime fiscal da transparência aos lucros de controladas e coligadas no exterior, valendo-se de regra já preexistente nas ordens nacionais, agora aplicada no âmbito internacional. O objetivo

Também denominados países de baixa ou nula tributação, de regime fiscal privilegiado ou de tributação favorecida. Embora não haja uma definição conceitual única, geralmente os paraísos fiscais conglobam como características comuns: i) a não-incidência do imposto de renda sobre pessoas jurídicas cujo capital pertença a não-residentes e que exerçam atividades exclusivamente offshore; ii) não-incidência de imposto de renda retido na fonte sobre remessas de dividendos e rendimentos pagos a terceiros no exterior; iii) legislação societária e financeira flexível e ampla liberdade cambial; iv) estabilidade política e econômica. O Relatório da OCDE, de 1998, elenca quatro critérios definidores: (a) ausência ou baixa tributação em impostos sobre o rendimento; (b) ausência de troca efetiva de informação; (c) falta de transparência sobre o funcionamento do sistema legislativo; (d) ausência de atividades substanciais. Cf. ORGANIZATION FOR ECONOMIC CO-OPERATION AND DEVELOPMENT (OECD). Harmful tax competition: an Emerging Global Issue. Paris: OECD Publications, 1998. p. 23 e ss. Já Carvalho e Bifano apontam os seguintes critérios no enquadramento de dada jurisdição como paraíso fiscal: a) não imposição de tributação, ou imposição em nível bastante reduzido, sobre determinadas pessoas e fatos, principalmente em relação à figura dos nãoresidentes e transações por eles realizadas. A comparação do nível da carga tributária (imposto sobre a renda) é normalmente em função da carga tributária média da região ou do próprio país, de forma isolada; (b) restrição quanto à divulgação de informações sobre a composição societária e titularidade, conceito esse introduzido no cenário jurídico brasileiro pela Lei n. 10.451/2002; e (c) excesso de flexibilidade de operação e falta de transparência quanto ao funcionamento do sistema bancário e cambial lato e strictu sensu. Cf. CARVALHO, Cassius Vinicius; BIFANO, Elidie Palma. Anotações sobre a tributação internacional da renda. In: SANTI, Eurico Marcos Diniz et al. (Coord.). Tributação internacional e dos mercados financeiro e de capitais. São Paulo: Quartier Latin, 2005. p. 290.

7 Taísa Maciel destaca que, além dos paraísos fiscais clássicos, algumas legislações estendem-se também a entes domiciliados em países de tributação normal, dotados de regimes fiscais prejudiciais, como as holdings luxemburguesas (que integram a lista brasileira de países com tributação favorecida), as SAFIs uruguaias (insertas na lista argentina), holdings holandesas ou belgas, entre outras. 
seria atingir a capacidade contributiva que teriam os sócios, caso interposição societária não houvesse. ${ }^{8}$

Gestava-se assim os primórdios de um regime de TLCE (Tributação dos lucros das Controladas e Coligadas estrangeiras), sigla em português para CFC rules.

O regime $C F C$ teve origem nos Estados Unidos, na década de 30, a partir das foreign personal holding companies de 1934 e as holding estrangeiras de $1937 .{ }^{9}$ As disposições Subpart $F$ derrogam a regra que condiciona a tributação dos lucros de controladas estrangeiras nos Estados Unidos ao momento de sua distribuição ao controlador norte-americano, autorizando - mediante cumprimento de certos requisitos a tributação independente de sua efetiva distribuição. ${ }^{10}$

$\mathrm{Na}$ esfera internacional, a questão subjacente à transparência assume ares de complexidade maior, já que o ente tributante sequer detém soberania para tributar a renda de sociedade transparente (pessoa jurídica domiciliada em outra jurisdição fiscal). ${ }^{11}$ Daí o termo de Tulio Rosembuj, ultraterritorialidade ofensiva, ${ }^{12}$ porquanto o país em que domiciliado o controlador roga-se de um alargamento de sua competência tributária, atingindo lucros de sociedade não-residente que não dispõe de estabelecimento permanente, em termos questionáveis perante os princípios e regras de tributação internacional.

O redirecionamento dos fatores produtivos brasileiros - profissionalmente coordenados para redução dos custos de transação e maximização de lucros - perpassa necessariamente (de modo cada vez mais intensificado) investimentos em outros países e economias (outbound $f l u x$ ), num trânsito e afluxo de capitais sem precedentes. A regulação desse trânsito financeiro tem especial importância no controle de condutas elisivas à arrecadação tributária, sobretudo no tocante aos chamados "paraísos fiscais". Ao mesmo tempo, porém, a regulação normativa não pode se rogar absoluta, sob pena

8 Cf. PADIAL, Ignacio Cruz. Transparencia fiscal internacional: régimen general y interrelación con los convênios de doble imposición. Valencia: Tirant lo Blanch, 2000. v. 13. p. 28.

9 Conforme dispõe Taísa Maciel, somente em 1962, quando o governo Kennedy incorporou a normação à Subpart $F$ do Código Tributário (Internal Revenue Service Code), o regime passou a ser conhecido mundialmente como Controlled Foreign Corporations CFC Subpart F Provisions [ou simplesmente CFC legislation, Subpart F rules ou CFC rules]. Cf. MACIEL, Taísa. Tributação dos lucros das controladas e coligadas estrangeiras. In: TÔRRES, Heleno Taveira (Coord.). Direito tributário internacional aplicado. São Paulo: Quartier Latin, 2005. v. 3. p. 207.

10 A origem e evolução histórica do regime CFC no Brasil ultrapassa o âmbito de competência deste trabalho. Para uma visão mais aprofundada acerca do tema, cf. LOTT, Maíra Carvalhaes. Tributação dos lucros no exterior: um contributo para o ordenamento jurídico brasileiro face à perspectiva do direito fiscal internacional e a práxis do direito fiscal europeu. Disponível em: <http:/www.fiscosoft.com.br/a/6098/tributacao-doslucros-no-exterior-um-contributo-para-o-ordenamento-juridico-brasileiro-face-a-perspectiva-do-direitofiscal-internacional-e-a-praxis-do-direito-fiscal-europeu-maira-carvalhaes-lott>. Acesso em: 25 fev. 2013.

11 Id. Ibid.

12 Cf. ROSEMBUJ, Tulio. Derecho fiscal internacional. Barcelona: El Fisco, 2001. p. 99. 
de interferir abusivamente no domínio econômico, em prejuízo do setor produtivo (e do próprio aumento de arrecadação).

Daí a essencialidade da discussão do regime de tributação da renda incidente sobre coligadas/controladas por empresas brasileiras, partindo da influência recíproca dos fenômenos econômico e jurídico, e tendo por baliza os princípios constitucionais em matéria tributária, mormente as limitações ao poder de tributar.

Especificamente quanto à tributação do imposto sobre a renda aferida além do território brasileiro, a comparação do regime brasileiro de bases universais - vigente até a reforma legislativa da Lei Federal n. 12.973/2014 - com o regime adotado pela maioria dos países com CFC rules implica a seguinte constatação básica: o regime brasileiro não guardava correspondência com nenhum outro ordenamento, ao não disciplinar até então quaisquer limitantes subjetivos (país de residência da empresa coligada ou controlada no exterior) ou objetivos (tipo de rendimento) na determinação da regra matriz de incidência tributária. ${ }^{13}$ Diante do peculiar esforço empreendido pelo Fisco federal no intuito de vedar condutas elisivas, o presente trabalho volta-se com curiosidade sobre a efetividade do modus operandi das exações, sua conformação legal e as implicâncias diretas no cenário macroeconômico e no desempenho do empresariado brasileiro no âmbito internacional.

13 O único país citado pela doutrina com igual regime é a Nova Zelândia. Cf. PEREIRA, Roberto Codorniz L. O regime especial de tributação de lucros auferidos no exterior. São Paulo: NEF - Núcleo de Estudos Fiscais da Escola de Direito de São Paulo da Fundação Getúlio Vargas, 2011. p. 4. 
2. A Lei n. 12.973/2014: o que mudou?

O novo quadro de CFC rules brasileiro, inaugurado pela Lei n. 12.973/2014, fruto da conversão da Medida Provisória n. 627/2013, ${ }^{14}$ traz em seu bojo importantes inovações, com vigência em princípio ${ }^{15}$ programadas para $1^{\circ}$ de janeiro de 2015 :

\subsection{O regime das controladas}

Em princípio, no que tange à tributação de controladas offshore, é mantida a regra geral de tributação automática mediante disponibilização ficta anual do IRPJ e da CSLL, haja ou não efetiva disponibilização à controladora brasileira.

Não obstante, a nova legislação prevê balizas mais concretas ao oferecimento dos rendimentos à tributação, coadunando-se com um apetite arrecadatório arrefecido ante à crescente organização, e principalmente, internacionalização, da classe empresária.

No bojo da contenção legislativa, tanto a variação cambial como outras parcelas incluídas no ajuste do investimento pela equivalência patrimonial (v.g.,

14 Motivada pela decisão do Supremo Tribunal Federal em sede concentrado de controle de constitucionalidade (ADI n. 2.588), e nos entendimentos mantidos com "grandes contribuintes", a MP n. 627/2013 introduziu relativas mudanças nas normas que dispõem sobre a tributação de controladas/coligadas offshore de controladoras brasileiras. Trata-se, grosso modo, de pacote de medidas fiscoregulatórias que aproximam o regime brasileiro - amplamente criticado pela doutrina, por este autor inclusive - de um regime CFC mais afeito às práticas internacionais recomendadas pela OCDE (Organização para Cooperação e Desenvolvimento Econômico). Embora o escopo do presente trabalho se debruce sobre os delineamentos legislativos da Lei n. 12.973/2014 e sua inflexão na política macroeconômica de governo, é importante ter em mente que o desforço legislativo é fruto de amplo espectro de construção normativa, de que coparticiparam vários envolvidos. A pluripotencialidade de interesses subjacentes é tal, que chegar a um regime de comum acordo envolve negociações "de elevador", travadas no mais das vezes fora das formalidades do Plenário. Embora sobre-exceda o escopo e amplitude desse trabalho, cita-se en passant os delineamentos previstos no curso da MP n. 627/2013, a posteriori convertida na hoje vigente Lei n. 12.973/2014, em especial: a permissão para que a controladora recolha o IRPJ e CSLL na proporção dos resultados auferidos offshore, ao longo de sua distribuição limitada a cinco anos máximos de diferimento, e distribuído o percentual mínimo de $25 \%$ logo no primeiro ano subsequente à apuração, sob reserva de informe prévio do contribuinte pela opção e desistência incondicionada de eventuais processos judiciais e administrativos em que discuta a matéria, e desde que a controlada (i) não esteja localizada em jurisdição com tributação favorecida (tax haven) tampouco se beneficie de regime fiscal privilegiado; (ii) não esteja sujeito a regime que tribute lucros à alíquota nominal inferior a 20\% (= subtributação); não seja controlada, direta ou indiretamente, por pessoa jurídica submetida aos tratamentos tributários de (i) e (ii); e (iv) tenha elemento reditual ativo equivalente ou superior a $80 \%$ da renda total. Outros delineamentos serão tratados, quando convenientes, no curso deste trabalho.

15 A Lei n. 12.973/2014 faculta aos contribuintes interessados a opção (irrevogável) pela retroatividade de sua vigência desde $1^{\circ}$ de janeiro de 2014, isto é, para o exercício de 2014. Cf. art. 96 da lei, verbis: “Art. 96. A pessoa jurídica poderá optar pela aplicação das disposições contidas nos arts. 76 a 92 desta Lei para o ano-calendário de 2014. $\S 1^{\circ}$ A opção de que trata o caput será irretratável e acarretará a observância de todas as alterações trazidas pelos arts. 76 a 92 a partir de $1^{\circ}$ de janeiro de 2014. $\S 2^{\circ}$ A Secretaria da Receita Federal do Brasil definirá a forma, o prazo e as condições para a opção de que trata o caput. ". 
diferenças contábeis e contingências em balanço patrimonial escrituradas como reservas) não integram a base de IRPJ e CSLL.

Eventuais prejuízos acumulados no período pré-lei n. 12.973/2014 poderão

ser compensados com os lucros gerados offshore sem limites de tempo e montante, desde que informados à autoridade fiscal na forma e prazo estabelecidos pela RFB.

Para cada ano-calendário, a controladora sediada em território nacional (ou a ela equiparada ${ }^{16}$ ), deverá escriturar - em subconta ${ }^{17}$ individualizada da conta de investimento em controlada direta no exterior - a variação do investimento equivalente aos lucros ou prejuízos auferidos pela própria controlada direta e suas respectivas controladas, direta ou indiretamente, no Brasil ou offshore, pelo montante proporcional à participação.

\subsubsection{A opção pela consolidação}

Aspecto controverso na sistemática $C F C$ então vigente, o debate acerca da permissividade à compensação de perdas offshore com lucros offshore fora - até antes da

16 Por sociedade offshore "controlada por equiparação" entende-se a investida coligada cuja pessoa jurídica investidora, em conjunto com pessoas físicas ou jurídicas residentes ou domiciliadas no Brasil ou no exterior, consideradas como vinculadas à investidora, possua mais de cinquenta por cento $(50 \%)$ do capital votante da coligada offshore. Por sua vez, para efeitos das novas CFC rules, o conceito de "pessoa vinculada" à investidora brasileira compreende, concomitantemente: (i) a pessoa física ou jurídica cuja participação societária no capital social da investidora a caracterize como controladora, direta ou indireta, desta última, na forma definida no parágrafo segundo do art. 243 da Lei das S.A. (Lei n. 6.404/1976), isto é, que detenha direitos de sócio que lhe assegurem, de modo permanente, preponderância nas deliberações sociais e o poder de eleger a maioria dos administradores da investidora; (ii) a pessoa jurídica que seja caracterizada como controlada, direta ou indireta, ou coligada, da investidora, conforme definição do parágrafo primeiro do art. 243 da Lei das S.A., isto é, entidades em que a investidora detenha "influência significativa" (= exercício do poder de participar nas decisões da política financeira ou operacional da investida, sem no entanto controlá-la, conforme parágrafo quarto do mesmo artigo), presumida ex lege quando o percentual de titulação societária exceder $20 \%$ (vinte por cento) do capital social; (iii) a pessoa jurídica quando esta e a empresa domiciliada no Brasil estiverem sob controle societário ou administrativo comum ou quando pelo menos $10 \%$ (dez por cento) do capital social de cada qual pertencer a uma mesma pessoa física ou jurídica; (iv) a pessoa física ou jurídica que seja sua associada, na forma de consórcio ou condomínio, conforme definido na legislação brasileira, em qualquer empreendimento; (v) a pessoa física que for parente ou afim até o terceiro grau, cônjuge ou companheiro de qualquer de seus conselheiros, administradores, sócios ou acionista controlador em participação direta ou indireta; e (vi) a pessoa jurídica residente ou domiciliada em país com tributação favorecida ou beneficiária de regime fiscal privilegiado, conforme dispõem os arts. 24 e 24-A da Lei n. 9.430/1996, quando não se possa demonstrar que os controladores correspectivos não são incursos nas hipóteses de incidência (itens I a IV) supracitadas.

17 Não obstante, parece-nos certo que em dadas hipóteses tal subconta não será a mais adequada para um tratamento fiscal escorreito de ativos e passivos objeto de reavaliação em balanço, mormente em virtude das mudanças de standard contábil (mais afeitas ao modelo IFRS) instituídas pela mesma Lei n. 12.973/2014. Eis porque, em síntese, o art. 68 do referido diploma confere à Receita Federal a faculdade de criar controles alternativos e/ou adicionais, a exemplo de distintas taxas de depreciação ou registro de bens objetos de arrendamento mercantil pela arrendatária. Nesse sentido, cf. ERNST \& YOUNG. Global Tax alert report (News from America Tax Center). In: Brazil enacts tax reform. Disponível em: $<$ http://www.ey.com/GL/en/ Services/Tax/International-Tax/Alert--Brazil-enacts-tax-reform>. Acesso em: 20 fev. 2015. 
edição da Lei n. 12.973/2014 - objeto da Instrução Normativa n. 213/2002, da Secretaria da Receita Federal do Brasil, disciplinando que a subsidiária estrangeira de primeiro nível seria responsável por consolidar os resultados dos escalões subsequentes (metodologia denominada "consolidação vertical").

$\mathrm{O}$ atual diploma aglutina no próprio balanço da controladora brasileira os resultados de suas subsidiárias offshore, independentemente da estrutura e complexidade societária do grupo, revogando o método de consolidação vertical, desde que obedecidas determinadas premissas postas pela lei.

Assim é que, no novo regime, o legislador estendeu à controladora brasileira $^{18}$ a possibilidade ${ }^{19}$ de consolidar os resultados auferidos por controladas no exterior, conquanto não verificadas as seguintes condições (cumulativas): ${ }^{20}$

i) a controlada estiver sediada em país que não tenha tratado ou ato com cláusula específica para troca de informações tributárias com o Brasil;

ii) a controlada estiver localizada em país ou dependência com tributação favorecida, ou esteja sob regime de subtributação; ${ }^{21}$

iii) a investida esteja sob controle ou intermediação, direto ou indireto, de entidade localizada em país ou dependência com tributação favorecida ou submetida a regime de subtributação; e

iv) a investida possua renda substantiva ${ }^{22}$ inferior a $80 \%$ da renda total.

18 A opção pela consolidação teve sua vigência limitada até o ano de 2022. Cf. art. 78 da Lei n. 12.973/2014, verbis: “Art. 78. Até o ano-calendário de 2022, as parcelas de que trata o art. 77 poderão ser consideradas de forma consolidada na determinação do lucro real e da base de cálculo da CSLL da controladora no Brasil, excepcionadas as parcelas referentes às pessoas jurídicas investidas que se encontrem em pelo menos uma das seguintes situações: (...)".

19 A exegese da dicção legal ("possibilidade") nos leva a crer que ao contribuinte é dado escolher - sob o pálio da otimização fiscal e de um planejamento tributário - qual(is) o(s) investimento(s) atinentes às respectivas investidas permitem uma efetiva economia tributária sob consolidação única em balanço da investidora, e portanto serão oferecidos sob o regime consolidado, e pari passu, quais não lhe serão vantajosos, deixando esses últimos sob regime de escrituração individual. Nesse sentido, confira-se o teor do art. $11, \S 7^{\circ}$, II, da IN RFB 1.520/2014, admitindo o exercício da opção parcial de consolidação, verbis: "\$ $7^{\circ}$ A opção pela consolidação de que trata este artigo: (...) II - pode ser aplicada de forma parcial, ou seja, incluindo os resultados das controladas diretas ou indiretas, no exterior, indicadas pela controladora no Brasil no Demonstrativo de Consolidação de que trata o art. 37.".

20 Sobrevindo quaisquer dessas hipóteses, a opção de consolidação será vedada à controladora autóctone.

21 Nos termos do art. 84, III, por regime de "subtributação" entende-se aquele que tributa lucros da pessoa jurídica domiciliada no exterior à alíquota nominal inferior a $20 \%$, modulável a até $15 \%$ mediante decreto do Poder Executivo.

22 A nova legislação confere elastério significativo ao conceito de "renda ativa" (active income), seja em relação ao estado anterior do regime legal brasileiro anti-deferral, seja em comparação com a própria MP $\mathrm{n}$. 627/2013 originária e após convertida. Consoante a Lei n. 12.973/2014, será "renda ativa própria" aquela obtida diretamente pela pessoa jurídica mediante exploração de atividade econômica própria, excluídas as seguintes receitas: i) royalties; ii) juros; iii) dividendos; iv) participações societárias; v) alugueis; vi) ganhos de capital, ressalvada - e aqui outra inovação legislativa pró-contribuinte - a alienação de participações 
Não obstante, será deferida excepcionalmente a consolidação mesmo em casos em que o país-sede da investida não mantenha acordo, ato ou tratado com a jurisdição brasileira para intercâmbio de informações tributárias. Para a tanto, a lei ${ }^{23}$ abre à controladora brasileira a possibilidade de ofertar espontaneamente a contabilidade societária de sua investida à administração tributária, em forma e prazo a ser definidos também pela RFB.

Na eventualidade da consolidação findar com saldo deficitário, o excesso de prejuízo será controlado de forma individual, e utilizado na compensação com lucros futuros das mesmas pessoas jurídicas offshore geradoras dos respectivos passivos, sob condição de que tais estoques de prejuízo sejam divulgados às agências reguladoras em forma e prazo preestabelecidos pela Receita Federal. ${ }^{24}$

A contrario senso, inexistindo opção pela tributação em bases consolidadas, ou diante de sociedades cuja consolidação seja, por quaisquer razões, inviável em face do escopo ou plexo de atividades desenvolvidas, os resultados positivos serão oferecidos à tributação ao término do ano-calendário, sob escrituração contábil individualizada. Analogamente, os resultados negativos serão amortizáveis da parcela superavitária atinente (apenas) às mesmas entidades offshore respectivas e geradoras de lucros, sob reserva, mais uma vez, de que os estoques de prejuízo sejam divulgados a priori em forma e prazo fixados por Instrução Normativa infralegal.

societárias ou ativos de caráter permanente adquiridos há mais de dois anos; vii) aplicações financeiras; e viii) intermediação financeira. Além da inclusão de ganhos de capital derivados de alienação de participações societárias ou ativos permanentes mantidos em carteira por mais de dois anos, o novo diploma considera como elementos redituais ativos os valores recebidos a título de dividendos ou receitas de participações societárias de investimentos efetuados até 31 de dezembro de 2013 em pessoa jurídica cuja receita ativa própria seja igual ou superior a oitenta por cento $(80 \%)$.

23 Cf. Art. $78, \S 7^{\circ}$ da Lei n. 12.973/2014, verbis: " $\$ 7^{\circ}$ Na ausência da condição do inciso I do caput, a consolidação será admitida se a controladora no Brasil disponibilizar a contabilidade societária em meio digital e a documentação de suporte da escrituração, na forma e prazo a ser estabelecido pela RFB, mantidas as demais condições.".

24 Vide o teor do art. 79, caput e incisos da novel legislação, in verbis: "Art. 79. Quando não houver consolidação, nos termos do art. 78, a parcela do ajuste do valor do investimento em controlada, direta ou indireta, domiciliada no exterior equivalente aos lucros ou prejuizos por ela auferidos deverá ser considerada de forma individualizada na determinação do lucro real e da base de cálculo da CSLL da pessoa jurídica controladora domiciliada no Brasil, nas seguintes formas: I - se positiva, deverá ser adicionada ao lucro líquido relativo ao balanço de 31 de dezembro do ano-calendário em que os lucros tenham sido apurados pela empresa domiciliada no exterior; e II - se negativa, poderá ser compensada com lucros futuros da mesma pessoa jurídica no exterior que lhes deu origem, desde que os estoques de prejuizos sejam informados na forma e prazo estabelecidos pela Secretaria da Receita Federal do Brasil - RFB.". Sobre esse mister, a Receita Federal disciplinou os requisitos e a temática do tratamento de prejuízos na Instrução Normativa IN RFB 1.520/2014, em especial em seu art. 38, ao elencar os elementos mínimos que deverão ser contidos no Demonstrativo de Prejuízos Acumulados no Exterior. 


\subsection{O regime das coligadas}

No tocante às sociedades coligadas, os novos parâmetros distinguem duas tipologias distintas: (i) as sociedades cujos resultados são oferecidos à tributação ao final do ano-calendário de efetiva disponibilização dos lucros; (ii) as sociedades cujos resultados são objeto de tributação automática e compulsória, quer se tenha ou não disponibilização espontânea de rendimentos.

$\mathrm{O}$ critério diferenciador assemelha-se às hipóteses de consolidação de resultados de investidas controladas. Destarte, integram o primeiro grupo, i.e., o das sociedades cuja regra-matriz tem por critério material o ato espontâneo de disponibilização aos sócios, as pessoas jurídicas que:

(i) não estejam sujeitas a regime de subtributação;

(ii) não estejam localizadas em país ou dependência com tributação favorecida ou com regime fiscal privilegiado; e

(iii) não sejam controladas, direta ou indiretamente, por pessoa jurídica sujeita a regime de subtributação.

São equiparados à condição de coligada os empreendimentos controlados em conjunto com partes não vinculadas. ${ }^{25}$

Em síntese, levando em conta a metodologia de inclusão dos lucros das sociedades estrangeiras na base tributável da empresa brasileira, depreende-se que:

(i) antes da Lei n. 12.973/2014, os lucros auferidos pelas coligadas eram tributados sob o regime de competência, do mesmo modo que as controladas. O Supremo Tribunal Federal, no entanto, no curso do julgamento da ADI n. 2.588, entendeu pela inconstitucionalidade da regra, sempre que tais empresas não fossem sediadas em paraíso fiscal; ${ }^{26}$

(ii) com o advento da Lei n. 12.973/2014, os lucros das coligadas estrangeiras passam a ser, via de regra, tributados pelo regime de caixa, enquanto que os lucros das controladas devem ser tributados pelo regime de competência. Nesse quadro, se sob enfoque superficial preliminar o diferimento aplicável aos lucros das coligadas no exterior ressoa atraente, a lei elimina doravante a possibilidade de uso do crédito de impostos pagos pela coligada sobre os seus lucros, fato último que pode acarretar aumento substantivo da carga

\footnotetext{
$25 \quad$ A respeito da vinculação de partes, cf. nota 17 deste trabalho.

26 Para uma análise circunstanciada dos desdobramentos da ADI n. 2.588, cf. item 3 deste trabalho.
} 
tributária do grupo empresarial.

Entrevista a nova conformação bipartida, pode-se chegar ao seguinte quadro-síntese da tributação em bases universais, hoje vigente:

Worldwide income taxation - após Lei n. 12.973/2014

\begin{tabular}{|c|c|c|c|c|}
\hline & $\begin{array}{c}\text { Controladas } \\
\text { (art. } 77 \text { da Lei n. } \\
12.973 / 2014 \text { ) }\end{array}$ & $\begin{array}{l}\text { Controladas por } \\
\text { Equiparação } \\
\text { (art. } 83 \text { da Lei n. } \\
\text { 12.973/2014) }\end{array}$ & $\begin{array}{c}\text { Coligadas } \\
\text { por regime de } \\
\text { competência } \\
\text { (art. } 82 \text { da Lei n. } \\
12.973 / 2014 \text { ) }\end{array}$ & $\begin{array}{c}\text { Coligadas por } \\
\text { regime de caixa } \\
\text { (art. } 81 \text { da Lei n. } \\
12.973 / 2014 \text { ) }\end{array}$ \\
\hline $\begin{array}{l}\text { Critério material } \\
\text { (da regra-matriz) }\end{array}$ & $\begin{array}{c}\text { Parcela do ajuste } \\
\text { do valor do } \\
\text { investimento } \\
\text { equivalente aos } \\
\text { lucros auferidos } \\
\text { pela controlada } \\
\text { antes do IR, } \\
\text { excetuando a } \\
\text { variação cambial }\end{array}$ & $\begin{array}{l}\text { Parcela do ajuste } \\
\text { do valor do } \\
\text { investimento } \\
\text { equivalente aos } \\
\text { lucros auferidos } \\
\text { pela controlada } \\
\text { antes do IR, } \\
\text { excetuando a } \\
\text { variação cambial }\end{array}$ & $\begin{array}{l}\text { Parcela do ajuste } \\
\text { do valor do } \\
\text { investimento } \\
\text { equivalente aos } \\
\text { lucros auferidos } \\
\text { pela controlada } \\
\text { antes do IR }\end{array}$ & Lucros auferidos \\
\hline $\begin{array}{l}\text { Critério temporal } \\
\text { (da regra-matriz) }\end{array}$ & $\begin{array}{l}\text { 31/12 do ano- } \\
\text { calendário em que } \\
\text { os lucros tenham } \\
\text { sido apurados pela } \\
\text { controlada (regime } \\
\text { de competência) }\end{array}$ & $\begin{array}{l}31 / 12 \text { do ano- } \\
\text { calendário em que } \\
\text { os lucros tenham } \\
\text { sido apurados pela } \\
\text { controlada (regime } \\
\text { de competência) }\end{array}$ & $\begin{array}{l}\text { 31/12 do ano- } \\
\text { calendário em que } \\
\text { os lucros tenham } \\
\text { sido apurados pela } \\
\text { controlada (regime } \\
\text { de competência) }\end{array}$ & $\begin{array}{c}\text { 31/12 do ano- } \\
\text { calendário em } \\
\text { que os lucros } \\
\text { tiverem sido } \\
\text { objeto de efetiva } \\
\text { disponibilização } \\
\text { (regime de caixa) }\end{array}$ \\
\hline $\begin{array}{c}\text { Admite } \\
\text { compensação }\end{array}$ & Sim & Sim & Não & Não \\
\hline $\begin{array}{l}\text { Exige subconta } \\
\text { individualizada }\end{array}$ & Sim & Sim & Não & Não \\
\hline
\end{tabular}

\subsection{As deduções}

Na eventualidade da controlada ou coligada offshore deter participação societária em sociedade brasileira, a parcela do lucro auferido pela pessoa jurídica 
brasileira poderá ser deduzida do lucro da controlada ou coligada offshore a ser oferecido à tributação no Brasil.

Ademais, os reclamos crescentes do empresariado brasileiro diante do nefasto efeito da bitributação sobre os investimentos feitos no exterior - nas hipóteses em que o mesmo elemento reditual preenche a regra-matriz do país de origem da renda, e portanto é ab initio tributada pela jurisdição da investida - trouxeram significante evolução legislativa: doravante é permitido à pessoa jurídica brasileira deduzir, na proporção de sua participação, o imposto de renda pago no exterior (inclusive o Imposto de Renda na Fonte sobre Dividendos - IRRF) pela controlada, direta ou indireta, sobre as parcelas positivas computadas no lucro real da controladora no Brasil, até o limite dos tributos sobre a renda incidentes no Brasil sobre as referidas parcelas. Restando saldo excedente após a compensação com a alíquota nominal efetiva do IRPJ, o crédito admitirá compensação até o limite da CSL. Evita-se assim uma sobretaxação potencialmente desestimuladora de investimentos externos por empresas brasileiras, cujos desdobramentos merecem também inflexão das políticas econômicas e do escopo de direcionamento de capitais realizado pela administração pública federal. ${ }^{27}$

Por fim, aprecatou-se também o legislador ao prever que, caso os lucros da controlada offshore somente perfaçam o fato imponível da jurisdição de origem em momento póstumo ao do oferecimento compulsório à tributação brasileira, a tributação alienígena admitirá compensação no Brasil, seja no ano em que verificada a incidência tributária, seja em ano posterior.

$27 \quad$ A maioria dos problemas econômicos desencadeados pela atual sistemática de tributação de lucros offshore decorre do descolamento entre a política tributária e uma preocupação mais efetiva com seus efeitos sobre a atividade empresarial brasileira. É essencial, para uma análise dessa inter-relação entre direito e economia, compreender o contexto em que insertas as empresas brasileiras a cada época, bem também as motivações que as levaram/levam ao desejo/necessidade de internacionalização produtiva e os conceitos subjacentes à matéria. Nesse contexto, a internacionalização de cadeias produtivas pressupõe uma economia aberta $\mathrm{e}$ de mão dupla, em que há um constante fluxo tanto de entrada de capitais no país (investimentos diretos de empresas multinacionais estrangeiras, os chamados inflow foreign direct investments ou inflow FDI), quanto de saída (investimentos diretos das empresas nacionais no exterior, ou outflow foreign direct investment/ outflow FDI). A doutrina cuida de esmiuçar duas vertentes distintas desse fenômeno de internacionalização: aquela comercial, isto é, voltada à parcela da produção nacional de bens e serviços cuja destinação compõe a pauta de exportação comercial dos respectivos países (e que não demanda prima facie a realocação de recursos diretamente no exterior, mas tão só a venda de mercadorias/serviços a outros países); aquela produtiva, cujo escopo é a movimentação dos fatores produtivos, e que pressupõe destarte uma relação contínua com o exterior e o emprego de capital produtivo fora do território de origem. Objeto de estudo deste trabalho - por integrar a sistemática de tributação de lucros offshore - será a internacionalização produtiva. Cf. BARRETO, Fernando Mello; RICUPERO, Rubens. A importância do investimento direto estrangeiro do Brasil no exterior para o desenvolvimento socioeconômico do país. In: ALMEIDA, André. (Coord.). Internacionalização de empresas brasileiras: perspectivas e riscos. Rio de Janeiro: Elsevier, 2007. p. 22. 


\subsection{A tributação "setorial": crédito presumido e dedutibilidade direcionada}

A consolidação legislativa é reflexo claro de inflexões político-econômicas na orientação das bases tributárias e no processo decisório do ente tributante em direcionar comportamentos desejados pela modulação fiscal. Trata-se de exemplo vivo de normaprêmio, ${ }^{28}$ orientada à concreção de comportamentos desejados pelo ordenamento, mediante introjeção de valores sociais, políticos, econômicos e/ou culturais predominantes.

Prefigura-se notória a preferência do executivo federal, recepcionada pelo

Congresso Nacional, em favorecer segmentos econômicos chave da produção econômica hodierna, dadas não só sua importância macroeconômica e os números robustos com que alavancam a economia, mas - e talvez principalmente - as externalidades positivas ${ }^{29}$ gestadas por tais segmentos e agentes, vis-à-vis outros vetores da matriz econômica brasileira.

Nessa esteira, até o ano-calendário de 2022, as controladoras brasileiras de sociedades estrangeiras que realizem atividades ${ }^{30}$ de fabricação de bebidas e produtos

28 A orientação de condutas pela cocriação normativa é fenômeno descrito de longa data pela doutrina, e magistralmente por Norberto Bobbio em seu A função promocional do direito. Em síntese, o ordenamento jurídico - enquanto subsistema autopoiético, na acepção luhmanniana - recria-se com assento em seus próprios elementos constitutivos. Essa âncora no autoreferenciamento permitiria uma inflexão sistêmica interna (o direito movendo e alternando suas próprias estruturas, com base na dualidade norma/não-norma, e no sein/nicht-sein), e ao mesmo tempo externa, incutindo nos tutelados pela norma comportamentos queridos/desejados ou proibidos/repelidos, depurando-se dessa dupla construção um subsistema social mais afeito à sociedade moderna hipercomplexa. Para mais detalhes acerca da teoria dos sistemas sociais, cf. NEVES, Marcelo. Entre Têmis e Leviatã: uma relação difícil. O estado democrático de direito a partir e além de Luhmann e Habermas. São Paulo: Martins Fontes, 2006. Para uma visão mais apurada da fenomenologia do direito influenciando os comportamentos sociais, veja-se a perspectiva bobbiana de indução via normas jurídicas premiais. Cf. BOBBIO, Norberto. Contribución a la teoria del derecho. São Paulo: Livraria dos Advogados, 1981. p. 324-325; BOBBIO, Norberto. A função promocional do direito. In: BOBBIO, Norberto. Da estrutura à função: novos estudos de teoria do direito. Barueri: Manole, 2007. p. 1-27.

29 A primeira referência ao que hoje se conhece por externalidade foi feita por Alfred Marshall, em 1925, em relação à curva de oferta descendente de uma indústria em regime concorrencial. O problema das externalidades ocorre quando os agentes econômicos interagem no mercado, gerando, sem intencionalidade, malefícios ou benefícios para indivíduos alheios ao processo. Entre as inúmeras conceituações possíveis, destacamos a de Carlos Alberto Longo, verbis: "Uma externalidade é uma imposição de um efeito externo causado a terceiros, gerada em uma relação de produção, consumo ou troca". Para um estudo aprofundado das externalidades, cf. SALGADO SOARES, Emília. Externalidades negativas e seus impactos no mercado. Dissertação (Mestrado) - Fundação Getúlio Vargas. Disponível em: <www.bibliotecadigital.fgv.br>. Acesso em: 6 nov. 2013.

30 Dentro do poder discricionário do Poder Executivo, a lei põe a salvo a possibilidade de decreto federal ampliar o rol de atividades beneficiárias do referido crédito presumido, o que efetivamente já fez o Ministério da Fazenda, mediante edição da Portaria MF n. 427/2014, cujo texto ampliou o rol de atividades para incluir as indústrias de transformação, extração de minérios e exploração, sob concessão, de bem público localizado no país de domicílio da controlada. Cf. Art. 86, $\S 10^{\circ}$ da Lei n. 12.973/2014, verbis: “§ 10. Até o ano-calendário de 2022, a controladora no Brasil poderá deduzir até 9\% (nove por cento), a título de crédito presumido sobre a renda incidente sobre a parcela positiva computada no lucro real, observados o disposto no $\S 2^{\circ}$ deste artigo e as condições previstas nos incisos I e IV do art. 91 desta 
alimentícios, assim como construção de edifícios e obras de infraestrutura, poderão se beneficiar de um crédito presumido equivalente a $9 \%$ dos lucros auferidos por suas investidas no exterior e computados no lucro real da controladora brasileira, observados os requisitos delineados nos incisos I e IV do art. 91 da Lei n. 12.973/2014, isto é, desde que a investida: (i) não esteja sujeita a regime de subtributação; e (iv) possua renda ativa própria igual ou superior a $80 \%$ de sua renda total. ${ }^{31}$

Igualmente, os lucros auferidos por controlada ou coligada offshore em virtude de atividades de afretamento por tempo ou casco nu, arrendamento mercantil operacional, aluguel, empréstimo de bens ou prestação de serviços diretamente relacionados à prospecção e exploração de petróleo e gás, em território brasileiro, não serão incluídos na base de cálculo do IRPJ e da CSLL, desde que cumpridos os seguintes requisitos pela investida controlada (direta ou indireta) ou coligada, nos termos do art. 77 , $\S \S 3^{\circ}, 4^{\circ}$ e $5^{\circ}$, da Lei n. 12.973/2014, verbis:

[seja] (...) I - detentora de concessão ou autorização nos termos da Lei n. 9.478, de 6 de agosto de 1997, ou sob o regime de partilha de produção de que trata a Lei n. 12.351, de 22 de dezembro de 2010, ou sob o regime de cessão onerosa previsto na Lei n. 12.276, de 30 de junho de 2010; II - contratada pela pessoa jurídica de que trata o inciso I (...).

\subsection{Possibile, ma non troppo: o diferimento pré-limitado no tempo}

Nos casos em que o resultado auferido offshore for objeto de automática tributação no Brasil findo o exercício respectivo, ao contribuinte é dada a opção de

Lei, relativo a investimento em pessoas juridicas no exterior que realizem as atividades de fabricação de bebidas, de fabricação de produtos alimentícios e de construção de edifícios e de obras de infraestrutura, além das demais indústrias em geral. \$11. O Poder Executivo poderá, desde que não resulte em prejuízo aos investimentos no País, ampliar o rol de atividades com investimento em pessoas jurídicas no exterior de que trata o $\$ 10 . "$.

31 Nesse mister, a regulamentação da Lei n. 12.973/2014, feita pela Receita Federal do Brasil a partir da Instrução Normativa IN RFB 1.520/2014 acresce (sem correspondência direta no texto legal originário) aos incisos I e IV precitados também as seguintes exigências: (a) que a empresa não esteja localizada em país ou dependência com tributação favorecida (blacklist) ou beneficiária de regime fiscal privilegiado (graylist); e (b) que a empresa não seja controlada, direta ou indiretamente, por empresa localizada em país ou dependência com tributação favorecida (blacklist) ou beneficiária de regime fiscal privilegiado (graylist). Cf. Art. $28, \S 2^{\circ}$, II e III, da IN RFB 1.520/2014, verbis: “ $§ 2^{\circ}$ O disposto no caput não se aplica às parcelas dos lucros decorrentes dos resultados oriundos de controlada, direta ou indireta, no exterior que: (...) II - esteja localizada em país ou dependência com tributação favorecida, ou não beneficiária de regime fiscal privilegiado, de que tratam os arts. 24 e 24-A da Lei n. 9.430, de 27 de dezembro de 1996; III - seja controlada, direta ou indiretamente, por pessoa jurídica submetida ao tratamento tributário previsto no inciso II do caput; (...)”. 
recolher o imposto: (i) anualmente; ou (ii) postergar a tributação mediante recolhimento, no primeiro ano, de $12,5 \%$ do tributo devido no Brasil, diferindo a parcela restante (de $87,5 \%$ ) para até o oitavo ano subsequente à apuração dos referidos resultados.

Originalmente, a Medida Provisória n. 627/2013 ${ }^{32}$ tratava a janela de diferimento com amplitude menor de cinco anos, em vez dos atuais oito anos, exigindo o oferecimento compulsório do equivalente a $25 \%$ do imposto total logo no primeiro ano, contra os atuais $12,5 \%$ previstos em lei.

Novamente, a reflexão dos critérios temporal e material (quantitativo) na composição da norma tributária atual é fruto do amálgama de interesses conflitantes entre o Fisco federal e a classe empresária brasileira, cada vez mais internacionalizada, e constitui objeto de contencioso não negligenciável junto ao Poder Judiciário e à esfera administrativa.

Embora alguns impasses sejam resolvidos com as novas bases imponíveis, restam pendentes de solução tópicos de grande relevância, tanto sob perspectiva de incremento arrecadatório aos cofres públicos, como de imobilização de ativos para contingenciar reservas em balanço, da parte do empresariado, em sua imensa maioria com papéis negociados em bolsa, e destarte com o condão de influenciar o comportamento de agentes econômicos, traders e analistas do mercado financeiro, e no limiar impactar a economia produtiva e o setor industrial em que insertas (quase todas de grande porte e participação significativa no Produto Interno Bruto). Trata-se de uma cadeia de relacionamentos extremamente sinérgica e interconectada, que ressignifica o ato legislativo em face da produção de efeitos econômicos e sociais de grandes proporções, quantitativa e qualitativamente.

Sem prejuízo do exposto, também são gestadas novas problemáticas a partir das soluções previstas, como se é de esperar diante da polêmica e do risco de passivo que envolve o tratamento da matéria.

A nova Lei n. 12.973/2014 não prevê um dispositivo condicionando o diferimento do imposto à desistência de processos pelo contribuinte discutindo a matéria, seja no âmbito judicial, seja na esfera administrativa, ao contrário do que previa inicialmente o texto da MP n. 627/2013 convertida.

Optando o contribuinte pelo diferimento protraído, ${ }^{33}$ os pagamentos efetuados do segundo ano em diante são acrescidos de juros à taxa LIBOR (London

32 Sobre a previsão legislativa originária da MP n. 637/2013, cf. nota 15 deste trabalho.

33 É importante ter em mente, seguindo a sistemática já delineada pelo diploma em questão, que a opção citada aplica-se apenas às sociedades controladas offshore: (i) cuja tributação não estiver sujeita a regime de tributação favorecida ou regime fiscal privilegiado; (ii) cuja sede não esteja alocada em país ou dependência fiscal com tributação favorecida ou regime fiscal privilegiado; (iii) que não sejam controladas, direta ou indiretamente, por pessoa jurídica localizada em país ou dependência fiscal com tributação favorecida ou 
Interbank Offered Rate), para depósitos em dólares americanos pelo prazo de doze meses, tendo por referência o último dia útil do mês civil imediatamente anterior ao vencimento, acrescidos da variação cambial monetária anual definida pro rata tempore pelo Banco Central do Brasil (BACEN), calculados em forma a ser regulamentada em Decreto executivo. Também os juros e acréscimos serão dedutíveis na apuração do lucro real, até o limite da base de cálculo da CSLL inclusive.

Para as hipóteses de fusão, spin-off, incorporação, encerramento de atividades ou liquidação da sociedade sediada em jurisdição brasileira, o tributo deverá ser quitado até a data do evento correspectivo (ou da extinção da pessoa jurídica).

Por fim, no que tange à titulação societária em entidades offshore por pessoas físicas residentes no Brasil, a inovação da Lei n. 12.973/2014 é clara, ao retirar do ordenamento as disposições atinentes à tributação desses elementos redituais. Destarte, a tributação sobre os rendimentos detidos por pessoa natural em sociedade offshore permanece condicionada à efetiva disponibilização, ${ }^{34}$ e grosso modo, à apropriação in pecuniae mediante repatriação dos recursos aos sócios.

\section{O que dizem nossos tribunais?}

A depuração do entendimento jurisprudencial demanda (breve) recontextualização com o julgamento da Ação Direta de Inconstitucionalidade (ADI) n. 2.588, pelo Plenário do Supremo Tribunal Federal. ${ }^{35}$

Em síntese, a requerente (Confederação Nacional da Indústria) questionava a constitucionalidade da regra prevista no caput do art. 74 da Medida Provisória n. 2.158$35 / 2001$, cuja dicção instituía um regime de oferecimento compulsório e automático à tributação, prima facie sem quaisquer balizas objetivas (critério de renda e/ou montante) ou subjetivas (percentual de titulação e grau de correlação da entidade coligada ou controlada com a sociedade brasileira). A tese da CNI era de que a incidência deveria ocorrer apenas no momento de efetiva distribuição dos resultados.

Ao examinar a constitucionalidade do art. $43, \S 2^{\circ}$ do CTN e do art. 74 da MP n. 2.158/2001, o Plenário da Corte se dividiu em quatro resultados:

com regime fiscal privilegiado; e (iv) que tenha elementos redituais ativos equivalentes a no mínimo oitenta por cento $(80 \%)$ da renda total auferida.

34 Sem descurar da importância do conceito e definição legal de "disponibilização", uma análise detida das diferenciações quanto às suas ressignificações jurídicas e econômicas - bem também eventual antinomia entre elas - é deixada a latere deste trabalho propositalmente, por razões de didática e de escopo. Para uma análise mais detida do tema, cf. DANIEL NETO, Carlos Augusto. Disponibilidade econômica e jurídica: breves colocações. Disponível em: <http://jusblogdodaniel.blogspot.com>. Acesso em: 4 abr. 2013.

35 Cf. ADI n. 2.588, Pleno do STF, Rel. Min. Joaquim Barbosa, j. 10/4/2013. Disponível em: <redir.stf.jus.br/ paginadorpub/paginador.jspdocTP $=\mathrm{AC} \& \operatorname{doc} \mathrm{ID}=63053>$. Acesso em: 20 mar. 2015. 
(i) inconstitucionalidade incondicional, já que o dia 31 de dezembro de cada ano estaria dissociado de qualquer ato jurídico ou econômico necessário ao pagamento de participação nos lucros;

(ii) constitucionalidade incondicional, seja em razão do caráter antielisivo (impedir "planejamento tributário") ou antievasivo (impedir sonegação) da normatização, ou devido à submissão obrigatória das empresas nacionais investidoras ao Método de Equivalência Patrimonial - MEP, previsto na Lei das Sociedades por Ações (Lei n. 6.404/1976, art. 248);

(iii) inconstitucionalidade condicional, afastada a aplicabilidade dos textos impugnados apenas em relação às empresas coligadas, porquanto as empresas nacionais controladoras teriam plena disponibilidade jurídica e econômica; e

(iv) inconstitucionalidade condicional, afastada a aplicabilidade do texto impugnado para as empresas controladas ou coligadas sediadas em países de tributação normal, com o objetivo de preservar a função antievasiva da normatização.

Em síntese, a composição conglobada do resultado implicou os seguintes efeitos práticos:

(i) a inaplicabilidade do art. 74 da MP n. 2.158-35 às empresas nacionais coligadas a pessoas jurídicas sediadas em países sem tributação favorecida, ou que não sejam tax havens; e

(ii) a aplicabilidade do art. 74 da MP n. 2.158-35 às empresas nacionais controladoras de pessoas jurídicas sediadas em países de tributação favorecida, ou desprovidos de controles societários e fiscais adequados (tax haven, assim definidos em lei).

Ou seja: somente em 2013 - em passivo judiciário de mais de doze anos - é que houve pronunciamento da Corte, declarando por maioria (apertadíssima) de seis votos a eficácia erga omnes, com efeito vinculante às demais esferas e instâncias políticoadministrativas e judiciárias, que a regra insculpida no pré-citado art. 74 - ao prever a incidência de IR e CSLL sobre resultados de empresas controladas ou coligadas no exterior, na data do balanço o qual apurados - aplica-se às controladas situadas em tax havens, não porém às coligadas sediadas em países sem qualquer tributação favorecida.

Embora a definição conceitual de "paraíso fiscal" esteja contida nos arts. 24 e 24-A da Lei n. 9.430/1996, o colegiado não vinculou seu comando decisório a este preceito normativo, evitando eventual ineficácia futura por mudanças na legislação 
ordinária federal. A contrario senso, o decisum orienta-se pelo conceito de "paraíso fiscal" na forma como "definido em lei".

Sem prejuízo, o Plenário não chegou a consenso acerca de outras questões trazidas pela requerente, cujo deslinde é de importância (e valores em contenda com o Fisco federal) não negligenciável. Não foi alcançada maioria, outrossim, no tocante à aplicação (ou não) da norma a controladas offshore fora de paraísos fiscais, bem como a coligadas sediadas em países de tributação favorecida ou ausente (tax haven). Nessas duas últimas hipóteses - justamente os borderline cases em que a pacificação jurisprudencial era a mais aguardada - inexiste definição, tampouco deliberação com eficácia própria do controle concentrado de constitucionalidade em sede de ADIs, i.e., efeito erga omnes e vinculante tanto horizontal quanto verticalmente às demais esferas e instâncias da Administração Pública.

Muito embora referido aresto tenha por escopo "pôr ponto final" à conturbada discussão doutrinária (e ao risco de passivo contencioso de proporções inigualáveis), a ata de julgamento da ADI n. 2.588 parte de conceitos legais cuja referência legislativa é per si ambígua e controversa, retroalimentando outro debate subjacente sobre os conceitos assim definidos em lei - de "coligada" e "paraíso fiscal".

Prima facie, o conceito de "coligada" é tratado tanto pelo Código Civil (art. 1.099, CC), como pela Lei de Sociedades Anônimas (art. 243, $\S 1^{\circ}$ ), e em ambos a fattispecie abstrata é divergente.

Com efeito, do cotejo dos referidos diplomas infere-se: a) confluência dos conceitos de sociedade controlada, qual seja, aquela cuja participação no capital social pela controladora garante preponderância nas deliberações sociais, incluída aí a prerrogativa de eleição da maioria de seus administradores; b) divergência sobre o conceito de coligada, visto que o critério adotado pelo Código Civil é eminentemente objetivo (basta a titulação em mais de $10 \%$ do capital social), ao passo que a legislação societária adota uma sistemática fluida e casuística, afeita à demonstração in concreto de uma significativa influência da investidora nos escopos políticos, financeiros e/ou operacionais da investida, sem o elemento de controle propriamente dito. Mesmo nas participações superiores a 20\% do capital votante, a LSA apenas presume a caracterização dessa influência (presunção iuris tantum, isto é, relativa, admitindo prova em contrário pelas sociedades interessadas). Além do exposto, da definição do julgamento da ADI n. 2.588 depreendese - embora ausente a vinculação legislativa expressa, como dito alhures - que o conceito de "paraíso fiscal" ao qual o aresto remete por reenvio seria aquele correspondente à atual definição de país com tributação favorecida, ${ }^{36}$ constante do art. 24 da Lei n. 9.430/1996,

36 Cf. GERMANO, Livia de Carli; BORGES, Alexandre Siciliano. ADIn 2588: acabou mesmo a discussão para "coligadas" fora de "paraíso fiscal"? Disponível em: < http://www.migalhas.com.br/ 
cujo suporte fático abstrato foi igualmente alvo de sucessivas modificações legislativas ao longo do tempo, e não necessariamente corresponde ao vocábulo "paraíso fiscal" tal qual sua acepção original. Com efeito, da primeira redação - afeita ao contexto da fixação das bases do regime de transfer pricing brasileiro - tinha-se por princípio o "país que não tribute a renda ou a tribute em alíquota máxima inferior a 20\%". Tal acepção, inclusive, norteou a edição das chamadas "listas" de paraísos fiscais pela Secretaria da Receita Federal, a partir das Instruções Normativas n. 164/1999 e 33/2001. Já em 2002, no entanto, a Medida Provisória n. 22 estendeu a aplicabilidade das normas de transfer pricing também a operações engendradas em jurisdições tributárias "cuja legislação interna oponha sigilo relativo à composição societária de pessoas jurídicas ou à sua titularidade", fato que ensejou, em ato contínuo, a edição da Instrução Normativa n. 188/2002 pela SRF, contemplando a relação de países ou dependências com tributação favorecida ou que oponham sigilo relativo à composição societária de pessoas jurídicas. A despeito da evolução administrativo-legal, a fattispecie abstrata do art. 24 da Lei n. 9.430/1996 permaneceu idêntica, encetando divergência de critérios na definição técnicojurídica de tax haven. Assim é que, para dadas aplicações (v.g., os aportes de investimento estrangeiro nos mercados financeiro e de capitais e depositary receipts, nos termos da Resolução CMN n. 2.689/2000, atualmente revogada - desde março de 2015 - pela nova Resolução CMN n. 4.373/2014), deveria ser considerado como standard a simples alíquota nominal efetiva de vinte por cento $(20 \%)$ ou menos, enquanto que às regras de transfer pricing, por exemplo, acrescia-se também a regra do sigilo atinente à composição societária.

Ora, a despeito do tratamento da Receita Federal - tomando-os por sinônimos, ou como se diferença inexistisse - cuida-se in casu de evidente disparidade intraordenamento, cuja incongruência é inadmissível sob o pálio do princípio constitucional da legalidade tributária, e corolário lógico, geradora de insegurança jurídica ao sujeito passivo tributário. ${ }^{37}$

dePeso/16,MI1 80512,21048-ADIn+2588+acabou+mesmo+a+discussao+para+coligadas + fora + de + parai so>. Acesso em: 20 abr. 2015.

37 Sem prejuízo do exposto, muito embora a Lei n. 11.727/2008 tenha estendido as hipóteses de incidência do art. 24 da Lei n. 9.430/1996, albergando também as jurisdições “cuja legislação não permita o acesso a informações relativas à composição societária de pessoas jurídicas, à sua titularidade ou à identificação do beneficiário efetivo de rendimentos atribuidos a não residentes" - de que adveio, pari passu a Instrução Normativa RFB n. 1.037/2010, revogando a IN SRF n. 188/2002 e passando a relacionar tais jurisdições em seu artigo primeiro - certos diplomas normativos continuam referindo-se-exclusivamente - ao critério da alíquota nominal efetiva, fato que em última instância implica a coexistência de sucessivas definições distintas a um mesmo instituto técnico-jurídico. 
Também o Superior Tribunal de Justiça (STJ) houve ocasião de se manifestar em 20 de maio de 2014, no Recurso Especial n. 1.325.709/RJ ${ }^{38}$ hoje pendente de julgamento de reclamo extraordinário perante o STF. No corpo do acórdão, a corte de uniformização infraconstitucional reconheceu - após grandes rusgas entre fisco e contribuintes - a prevalência dos Tratados para evitar a Dupla Tributação (TDTs) sobre eventuais regras antidiferimento $C F C$, para que os lucros auferidos pelas controladas da recorrente sediadas na Bélgica, Luxemburgo e Dinamarca fossem tributados apenas pelas respectivas jurisdições locais. Trata-se de precedente jurisprudencial há muito aguardado, cujo potencial passivo subjacente está entre os maiores já discutidos pelo Poder Judiciário brasileiro. $^{39}$

Embora amainadas as expectativas - e principalmente, o caloroso debate doutrinário gestado ex ante - a definição da prevalência de TDTs sobre a legislação interna, nas hipóteses de lucros offshore por sociedades empresárias sediadas no Brasil, não foi uniformemente seguida, em especial no âmbito administrativo.

Contrariando a posição do STJ, a Primeira Sessão de Julgamento do Conselho Administrativo de Recursos Fiscais (CARF) prolatou decisão a contrario senso em 5 de março de 2015, no curso do Processo Administrativo n. 10980.724003/2011-61.

In casu, a turma negou provimento - por voto de minerva - ao Recurso Voluntário interposto pela All America Latina Logística S/A, decidindo pela não aplicação do Tratado para evitar a Dupla Tributação de que eram signatários Brasil e Argentina, e reconhecendo ipso facto devido o recolhimento do IRPJ e da CSLL brasileiros sobre os lucros auferidos pela controlada argentina. Segundo o entendimento do relator, a tributação não incidiria sobre os lucros da sociedade sediada offshore, mas apenas sobre o reflexo patrimonial desta nos lucros auferidos pelos sócios brasileiros, razão pela qual inexistiria, a priori, conflito com dispositivos do Tratado.

Nesse diapasão, a despeito de pretensa fixação de balizas interpretativas mais sólidas - a partir do recente julgamento no âmbito do STJ - os tribunais administrativos têm assumido posicionamentos diversos (e por vezes contrastantes entre si), trazendo (mais) insegurança jurídica à celeuma. Apenas a título de ilustração, traz-se a lume um quadro-síntese ${ }^{40}$ dos entendimentos administrativos, concomitantemente favoráveis e

38 Recurso Especial n. 1.325.709/RJ, $1^{\text {a }}$ Turma do STJ, Rel. Min. Napoleão Nunes Maia Filho, j. 24/4/2014. Disponível em:

$<$ https://ww2.stj.jus.br/processo/revista/documento/mediado/componente=ITA\&sequencial=1275096\&n um_registro $=201201105207 \&$ data $=20140520 \&$ formato $=P D F>$. Acesso em: 20 abr. 2015.

39 Para se ter uma noção do tamanho do contencioso em discussão, o passivo potencial abrange as dez maiores empresas nacionais de capital aberto, cuja somatória de demandas judicializadas alcança a cifra aproximada de R\$ 134,4 bilhões. Cf. PEREIRA, Roberto Codorniz L. O regime especial ... cit.

40 Em todas as decisões administrativas, a controvérsia versava: (i) a aplicação do art. $7^{\circ}$ do Tratado contra a Dupla Tributação celebrado entre Brasil e a jurisdição tributária do país respectivo, vis-à-vis o art. 74 da MP 
desfavoráveis à prevalência dos TDTs sobre as regras $C F C$ estatais na determinação da regra-matriz de incidência tributária, prolatados por diferentes composições do CARF, mesmo após a publicação do Recurso Especial n. 1.325.709/RJ:

\section{Jurisprudência administrativa - Quadro-síntese}

\begin{tabular}{|c|c|c|c|c|}
\hline Acórdão & Sujeito passivo & Sessão & TDT & Resultado \\
\hline $1201-001.024$ & $\begin{array}{c}\text { Rexam Beverage } \\
\text { Can South America } \\
\text { S/A }\end{array}$ & $6 / 5 / 2014$ & Brasil-Chile & Pró-fisco \\
\hline $1402-001.713$ & $\begin{array}{c}\text { Camargo Corrêa } \\
\text { Cimentos S/A }\end{array}$ & $3 / 6 / 2014$ & Brasil-Argentina & Pró-fisco \\
\hline Não publicado & Petrobras S/A & $21 / 10 / 2014$ & Brasil-Holanda & $\begin{array}{c}\text { Parcialmente } \\
\text { pró-contribuinte } \\
\text { (exceção à CSLL) }\end{array}$ \\
\hline $1102-001.247$ & $\begin{array}{c}\text { Intercement Brasil } \\
\text { S/A }\end{array}$ & $25 / 11 / 2014$ & Brasil-Argentina & $\begin{array}{c}\text { Parcialmente } \\
\text { pró-contribuinte } \\
\text { (exceção à CSLL) }\end{array}$ \\
\hline $1302-0201.630$ & Petrobras S/A & $4 / 2 / 2015$ & Brasil-Holanda & Pró-fisco \\
\hline
\end{tabular}

Como entrevisto, um mesmo sujeito passivo, interpondo recursos voluntários perante a mesma instância administrativa, auferiu - em curtíssimo intervalo de tempo diferentes decisões, com entendimentos diametralmente opostos acerca da prevalência ou não de tratados internacionais sobre a aplicabilidade de $C F C$ rules brasileiras.

No acórdão n. 1302-0201.630, o conselheiro relator atribui aos lucros auferidos e não distribuídos por controladas holandesas da recorrente a natureza jurídica de dividendos, atraindo a incidência do art. $10^{\circ}$ do TDT, e não do art. $\mathbf{7}^{\mathbf{0}}$ do mesmo diploma, que disciplina a tributação de lucros no âmbito entre-países. Embora o voto condutor tenha sido acompanhado por outros conselheiros, também estes - a despeito da convergência de soluções concretas - embasaram sua construção em outros fundamentos jurídicos, ${ }^{41}$ recriando a expectativa de que a disparidade de decisões prolatadas seja objeto de uniformização administrativa no âmbito da Câmara Superior de Recursos Fiscais.

n. 2.158-35/2001; e (ii) o art. $10^{\circ}$ do TDT, em face da fattispecie abstrata que preceitua a disponibilização ficta dos dividendos como fato gerador. Adicionalmente, o acórdão n. 1102-001.247 cuidou - além dos arts. $7^{\circ}$ e $10^{\circ}$ citados - do art. 23, TDT, em contraste ao critério material do fato imponível, definido mais uma vez pela disponibilização ficta dos dividendos à controladora. Cf. NEDER, Marcos. O impasse dos tratados na tributação de lucros de controladas no exterior. Disponível em: $<$ http://jota.info/o-impasse-dos-tratadosna-tributacao-de-lucros-de-controladas-no-exterior>. Acesso em: 20 abr. 2015.

41 Cite-se, e.g., a justificativa também levantada noutros votos de que os investimentos de controladas avaliadas pelo Método de Equivalência Patrimonial (MEP) seriam representativos de disponibilidade econômica e acréscimo patrimonial imediato à empresa brasileira, dada a obrigação desta em computar no balanço contábil os lucros ainda não distribuídos de suas investidas. Tal obrigação proviria não da legislação tributária, mas da própria Lei de Sociedades Anônimas. Corolário do exposto, tratando-se de obrigação 
Embora esclareça aspectos tributários relevantes ao cenário de internacionalização do empresariado brasileiro, a nova legislação não resolveu de modo satisfatório o litígio sobre a medida exata da autolimitação dos Estados diante de tratados celebrados com outras jurisdições tributárias, tampouco em que medida seriam tais TDTs limitativos e/ou prevalentes ao escopo normativo de CFC rules de previsão ordinária e interna.

Em igual medida, deixa a desejar quando inova ao alterar a base tributante no Brasil para incidir sobre o "ajuste" do valor dos investimentos equivalente ao lucro de controladas offshore, cujo desdobramento em face de sua compatibilidade constitucional engendra ainda terreno fértil a discussões.

\section{Sobre o novo regime: (uma) crítica (possível)}

A reorientação dos centros político-decisórios de poder foi (e continua sendo) um processo contínuo de conformação a um novo cenário econômico de circulação de bens, recursos e pessoas, que no limite transmuda as bases conceituais do Estado-nação, nos moldes dantes delimitados pela política de Maquiavel e dos teóricos absolutistas da Era Moderna, a um Estado-transnacional, de alcance e extensões além-fronteira.

Tal fato ensejou pari passu a atualização consentânea das políticas e categorias tributárias adotadas pelos países, à medida que o clássico modelo de tributação territorial não mais dava conta da complexidade econômica e social dos novos fatos imponíveis, gerando perdas arrecadatórias significativas. Como reação em cascata à maior mobilidade de capital, a adoção conjunta de tais medidas fisco-regulatórias fez recrudescer não só a carga tributária, mas a concorrência fiscal entre os países pela atração das hipóteses de incidência em que pretensamente incursos os contribuintes na esfera internacional.

A par da trajetória da evolução normativa brasileira da sistemática $C F C$ rules, a normação tupiniquim destoava - até a recente Lei n. 12.973/2014 - abruptamente do modelo recomendado pela OCDE, dada a regra anti-deferral de viés absoluto e incapaz de discriminar a natureza passiva ou ativa dos rendimentos ou a origem reditual em paraísos fiscais ou jurisdições tributárias de regular tributação.

que extrai sua pertinência jurídica da lei comercial, sequer seria necessário recorrer ao plexo de normas tributárias - tanto menos aos tratados TDT eventualmente celebrados pelo Brasil com a jurisdição sede da sociedade investida - para inferir que os lucros desta implicam acréscimo patrimonial incontinenti à investidora respectiva, au fur et à mesure de sua disponibilização econômica. Daí porque os lucros auferidos offshore seriam passíveis de tributação no Brasil, exista ou não tratado internacional com a jurisdição de origem da fonte reditual. 
Sobre o efeito econômico adverso causado pelo sistema brasileiro de CFC rules, embora a tributação não seja fator determinante per si à desistência à internacionalização produtiva, é certo que gera um ônus concorrencial às empresas brasileiras, quando comparadas às competidoras em mercados globais, à medida que veda o diferimento da tributação nacional. Além disso, a não homologação de medidas isentivas alienígenas, a insegurança jurídica na interpretação e aplicação da lei em sede administrativa e a desarmonia com os Tratados celebrados pelo Brasil para evitar a dupla tributação reforçam o posicionamento consignado, de que se impõe às sociedades empresárias brasileiras um ônus concorrencial desmesurado e não incorrido pelas competidoras internacionais, fato último que, no limiar, poderia comprometer a expansão produtiva de agentes econômicos sem fôlego (leia-se capital de giro) para bancar margens de lucro e market share estrangulados pelo apetite arrecadatório do Fisco.

4.1. Sobre a aplicabilidade das $C F C$ rules em face dos tratados internacionais: celeuma longe de resolvida

É de fundamental relevância a harmonização da extensão e aplicabilidade do plexo de $C F C$ rules atuais ${ }^{42}$ com eventuais tratados celebrados com outros entes nacionais, em matéria de cooperação internacional para evitar os efeitos da bitributação. Nesse ínterim, o art. $7^{\circ}$ do Modelo OCDE constituiria norma de competência exclusiva do país de domicílio da investida (empresa que aufere o lucro efetivamente), e não do país de domicílio dos sócios-investidores..$^{43}$ Corolário lógico, tratando-se de empresas

42 Sem prejuízo da centralidade das discussões, a Lei n. 12.973/2014 resvala também em pontos de indefinição normativa intralegislativa, donde extraímos as seguintes questões para debate da doutrina:

a) Art. 76 da Lei n. 12.973/2014: o "registro individualizado" a ser levantado em subconta do ativo não disciplina quais os Generally Accepted Accounting Principles a ser utilizados, isto é, se os GAAP locais ou os aferentes à jurisdição tributária nacional brasileira, tampouco se o "lucro" in quaestio é o lucro líquido antes ou depois do IR. Em interpretação sistêmica dos arts. 77 e 95 da lei, poder-se-ia, prima facie, concluir que se trata do GAAP local, e do lucro antes da incidência de IR. As diferenças eventuais entre o valor do ajuste sujeito à tributação e a equivalência seriam computadas em conta residual;

b) Art. 77 da Lei n. 12.973/2014: embora procure disciplinar a questão do prejuízo acumulado nos anoscalendário anteriores, qual seria o tratamento aplicável às hipóteses de grupos empresariais complexos dotados de mais de uma cadeia de controle: o "carry-on" do prejuízo acumulado seria centrado na controlada de origem ou na controlada direta que consolidou as controladas indiretas? E por fim, qual seria o tratamento do prejuízo acumulado existente antes da aquisição da controlada pela controladora brasileira?

c) Art. 90 da Lei n. 12.973/2014: na opção pelo parcelamento, tratando-se de hipótese de deferral autorizado (até o $8^{\circ}$ ano subsequente, para recolhimento compulsório da parcela de $87,5 \%$ remanescente), os juros LIBOR serão dedutíveis na apuração do IRPJ e da CSLL. Nesse mister, quid est da variação cambial acumulada do período, diante da hipótese de descasamento cambial? Um ganho de dívida integra a base de cálculo da tributação? E uma perda nos dividendos, será dedutível?

43 Cf. XAVIER, Alberto. Equívocos e sofismas em matéria de lucros no exterior. Disponível em: <http://www. editorajc.com.br/2012/03/equivocos-e-sofismas-em-materia-de-lucros-no-exterior/>. Acesso em: 14 abr. 2015. 
brasileiras investidoras, direta ou indiretamente, de países com os quais a jurisdição brasileira mantenha tratado contra a dupla tributação, a "regra de ouro" - noyau dur ou essência de ser do diploma interestatal - é o art. $7^{\circ}$ do Modelo OCDE, cujo tipo contém fundamento óbvio: se ao país-sede da matriz é dado tributar os lucros de filiais e sucursais (estabelecimentos permanentes desprovidos de personalidade jurídica), no tocante às entidades personificadas (i.e., controladas ou coligadas), a competência exclusiva (e com isto leia-se impeditiva à de qualquer outra jurisdição) será atribuição do Estado de domicílio destas últimas entidades.

A despeito da clareza hialina do preceito normativo - claramente uma moldura restritiva aos limites do poder de tributar, no plano interestatal e transnacional, a que se autoimpõem ${ }^{44}$ de comum acordo os Estados cocontratantes - a aplicabilidade dos tratados internacionais de que é signatária a República Federativa do Brasil tem sido alvo de sucessivas contestações da autoridade tributária federal, sob alegação de dois argumentos primaciais.

Primeiro, ao afirmar que a legislação brasileira corresponderia aos standards CFC rules, normas por princípio consideradas aceitas e compatíveis com o art. $7^{\circ}$ dos tratados pela própria OCDE. Ora, não só prefigura-se desarrazoado equiparar o regime brasileiro aos standards $C F C$, como a própria aplicabilidade destes - nos termos do reiterado pela OCDE - subsume-se aos primados da: (i) excepcionalidade; (ii) caráter

44 Vide, a respeito, o posicionamento do Professor Luís Eduardo Schoueri, com espeque em Klaus Vogel: Vogel refere-se aos acordos de bitributação como uma máscara aposta sobre o direito interno, tapando determinadas partes deste. Nessa máscara haveria buracos, correspondentes aos casos em que o acordo permite o livre exercício da pretensão tributária do Estado. Assim, os dispositivos que continuarem visíveis, por meio de buracos contidos na máscara, são aplicáveis, enquanto os demais não. $\mathrm{O}$ autor também esclarece que há possibilidade de existirem buracos na máscara, mas não haver nenhum conteúdo visível. Trata-se dos casos em que o Estado não legislou sobre aquele tributo, muito embora não tenha se limitado no plano internacional ao exercício dessa competência. Tratando da explicação proposta por Vogel, Schoueri consigna ser boa perspectiva da harmonização entre os planos interno e internacional, porque, entre outras razões, mostraria que o tratado não revoga lei interna, apenas prevalece, ou seja, afasta sua aplicabilidade. A lei interna continua válida, mas tem sua aplicação (leia-se eficácia) contida. Trata-se de uma autolimitação da pretensão tributária do Estado, não podendo mais este fazer incidir sua regra de incidência sobre as situações comprometidas internacionalmente. Retoma-se assim o conceito de autolimitação da soberania, sob o primado de que, no contexto internacional atual - que impõe uma cooperação cada vez maior entre os países - é necessário que os Estados coarctem sua própria soberania (no fenômeno referido por Jhering como regra da autolimitação). Sobre o assunto, Betina Treiger Grupenmacher esposa o seguinte entendimento: “(...) em matéria tributária, especialmente, é possível afirmar-se a prevalência dos tratados sobre dispositivo de lei interna após a sua aprovação por decreto legislativo, pelo critério da especialidade, pois os tratados são normas especiais, ao passo que a lei interna tem a nota da generalidade”. Cf. SCHOUERI, Luís Eduardo. Tratados e convenções internacionais sobre tributação. Direito Tributário Atual, São Paulo, v. 17, p. 20-49, 2003. p. 35; GRUPENMACHER, Betina Treiger. Tratados internacionais em matéria tributária e ordem interna. São Paulo: Dialética, 1999. p. 107; PINTO, Gustavo Mathias Alves. Tratados internacionais em matéria tributária e sua relação com o direito interno no Brasil. Revista Direito GV, São Paulo, v. 4, n. 1, jun. 2008. Disponível em: $<$ http://www.scielo.br/scielo.phpscript=sci_arttext\&pid=S180824322008000100 007\&lng=en\&nrm=iso >. Acesso em: 14 abr. 2013. 
antielisivo; (iii) à localização da entidade controlada/coligada em jurisdição tributária favorecida; e (iv) ao aspecto eminentemente passivo (não-produtivo) do elemento reditual sujeito à incidência da norma. Atendo-se primeiro à legislação brasileira da MP n. 2.158$35 / 2001$, trata-se de clara norma distópica a qualquer enquadramento possível como $C F C$, haja vista que a sistemática antideferral adotada pela Medida Provisória em tela era absoluta, e não comportava quaisquer considerações objetivas (tipo de elemento reditual sujeito à disponibilização automática) ou subjetivas (grau de vinculação entre investidora e investida, entre outros). No tocante ao novo modelo instituído pela Lei n. 12.973/2014, ainda que se admitisse - em esforço interpretativo - que os novos parâmetros estariam mais afeitos aos standards internacionais, há hipóteses em que permanece mantida a disponibilização compulsória, independentemente do tipo de atividade empreendida offshore, ${ }^{45}$ e por conseguinte, não nos parece plausível acatar a tese de enquadramento como $C F C$ rules nos modelos preconizados pela OCDE (pautados, prima facie, pela excepcionalidade e pela situação de abuso).

Segundo, por considerar que sequer seria o caso de evocar a aplicação de tratado internacional, haja vista que nos estritos termos do que preceitua a legislação ordinária interna, o Brasil nada mais estaria que tributando o sujeito passivo brasileiro (a sociedade controladora brasileira), em virtude de elemento reditual (lucro dessa mesma sociedade) por ela percebido. Trata-se, aqui, de argumento falacioso, à medida que considera que o lucro (objeto de tributação) é auferido pela própria empresa brasileira longa manus, de sorte a sequer suscitar conflito de normas, tampouco aplicação de tratados contra a dupla tributação. ${ }^{46}$ Ora, o argumento prefigura-se insustentável per si. Por princípio, porque o lucro tributável in quaestio é o lucro da empresa estrangeira, imbuida de personalidade, estatuto e patrimônio jurídico próprios, por ela produzido, apurado e constituído. Essa, ademais, a parcela reditual (= lucro) a que faz menção o já citado art. $7^{\circ}, \S 1^{\circ}$ do Modelo OCDE, ao reservar à competência exclusiva do Estado de domicílio da investida o poder tributante correspectivo, com exclusão (óbvia e pleonástica) de qualquer outra, incluindo-se aí também a competência tributária do Estado de domicílio da sociedade investidora.

Destarte, inexistindo prévia distribuição espontânea dos lucros produzidos, o mesmo elemento material (= lucro acumulado pela sociedade estrangeira) somente

45 Caso das investidas controladas, controladas por equiparação e coligadas tributadas por regime de competência. Cf. arts. 77, 82 e 93 da Lei n. 12.973/2014.

46 Segundo esse raciocínio - que nos limitamos a afirmar "obtuso" - a jurisdição brasileira estaria no bojo de suas faculdades e competências tributárias plenas, ao impor o oferecimento à tributação de elemento reditual (= lucro) afeito à regra-matriz correspectiva, percebido por sujeito passivo tributário por excelência integrante da relação jurídico-tributária (= a sociedade controladora sediada em jurisdição nacional). 
poderá ser considerado lucro da entidade brasileira, ${ }^{47}$ caso sobrevenha imputação fictícia de lucro pelo Estado de domicílio da investidora, mediante mecanismo jurídico artificial. Nesse diapasão, o próprio método aditivo ${ }^{48}$ consagrado pela jurisdição brasileira - referenciado pela Instrução Normativa n. 213/2002, em seu art. $1^{\mathrm{o}}, \S 4^{\mathrm{o} 49}-$ reafirma que o objeto da tributação pela lei brasileira é o lucro da empresa estrangeira, que per si não é parte integrante, e tampouco se confunde, com o lucro da empresa matriz/ controladora brasileira, haja vista ser a esta adicionado, na qualidade estrita de lucro estrangeiro, ${ }^{50}$ para efeito póstumo de tributação pelo fisco tupiniquim.

47 Fenômeno que Alberto Xavier jocosamente denomina de "milagre da multiplicação", ao tratar da inadmissibilidade de imputar à investidora brasileira a titularidade imediata e consentânea de lucros produzidos, gestados e acumulados no bojo de entidade jurídico-societária própria e individualizada (a investida em grau de controlada ou coligada). Para uma análise mais detida, cf. XAVIER, Alberto. Direito tributário ... cit.

48 Também denominado "método bifásico", trata-se de metodologia de apuração segundo a qual, em primeiro estágio, determina-se a apuração do lucro da sociedade estrangeira, e em fase logicamente subsequente, impõe-se a adição daquele ao lucro líquido da sociedade controladora, para efeitos de apuração e determinação do lucro real desta última. Em síntese, importa a consideração de que o lucro real da investidora é bipartido em dois elementos distintos: (i) seu próprio lucro líquido; e (ii) o lucro proveniente do investimento vertido na sociedade estrangeira. Sua aplicação no direito brasileiro deflui do art. 25 , § $2^{\circ}$ da Lei n. 9.249/1995, verbis: “(...) $\S 2^{\circ}$. Os lucros auferidos por filiais, sucursais ou controladas, no exterior, de pessoas controladas, no exterior, de pessoas juridicas domiciliadas no Brasil serão computados na apuração do lucro real com observância do seguinte: I - as filiais, sucursais e controladas deverão demonstrar a apuração dos lucros que auferirem em cada um de seus exercícios fiscais, segundo as normas da legislação brasileira; II - os lucros a que se refere o inciso I serão adicionados ao lucro líquido da matriz ou controladora, na proporção de sua participação acionária, para apuração do lucro real".

49 Art. $1^{\circ}, \S 4^{\circ}$ da Instrução Normativa n. 212/2002, verbis: "os lucros de que tratam esse artigo serão adicionados ao lucro líquido, para determinação do lucro real e da base de cálculo da CSLL da pessoa jurídica do Brasil, integralmente, quando se tratar de filial ou sucursal, ou proporcionalmente à sua participação no capital social, quando se tratar de controlada ou coligada".

50 Dispõe o art. $7^{\circ}$ do Modelo OCDE sobre a tributação do lucro empresarial: "Os lucros de uma empresa de um Estado Contratante só são tributáveis nesse Estado; a não ser que a empresa exerça sua atividade no outro Estado Contratante, por meio de um estabelecimento permanente ali situado. Se a empresa exerce suas atividades na forma indicada, os lucros podem ser tributados no outro Estado, mas unicamente na medida em que forem atribuiveis àquele estabelecimento permanente". Em síntese, cumpre distinguir os regimes tributários incidentes sobre a renda auferida diretamente pela empresa (filiais e estabelecimentos permanentes), e os que não, como corolário dos princípios de certeza e segurança jurídica. Nas convenções para evitar dupla tributação, o conceito de estabelecimento permanente assume duas funções primaciais. Em primeiro plano, serve como critério de conexão subjetivo, vinculando para fins tributários a pessoa jurídica não-residente ao território em que instalado (a chamada função positiva do estabelecimento permanente). Segundo atributo é o de limitação à competência do estado de residência sobre rendimentos auferidos por residente seu em outro Estado. A contrario senso, aponta o Professor Heleno Tôrres que o permanent establishment configura também um limite objetivo ao Estado da fonte, pela exigência de dados pressupostos à qualificação da pessoa não residente como dotada de um estabelecimento permanente. Assim, enquanto a presença da pessoa não-residente não se configurar como tal, a competência tributária ativa será deferida in totum ao estado de residência, excluindo o estado da fonte mediante isenção, vis-à-vis a prevalência de aplicação da convenção internacional. Cf. TÔRRES, Heleno Taveira. Lucros auferidos por meio de controladas e coligadas no exterior. In: TÔRRES, Heleno Taveira (Coord.). Direito tributário internacional aplicado. São Paulo: Quartier Latin, 2005. v. 3. p. 110. Veja-se, por todos, o trabalho de Paulo Caliendo sobre a temática do estabelecimento permanente: CALIENDO, Paulo. Estabelecimentos 
Nada obstante, a simples técnica de equivalência patrimonial - escolhida para dar concreção à “adição" à parcela do lucro líquido da investidora - não é suscetível de "transformação" 51 miraculosa do lucro alienígena em lucro brasileiro, como se ambos fossem $a b$ initio equivalentes ou coincidentes. ${ }^{52-53}$

\subsection{Da (in)constitucionalidade do novo sistema brasileiro CFC rules}

Em relação à análise jurídica da constitucionalidade do regime, nos parece que, sempre que incidir sobre operações produtivas de internacionalização econômica (i.e., favoráveis ao desenvolvimento econômico brasileiro), um regime CFC rules assumirá inconstitucionalidade incontornável.

Para além do conceito constitucional de renda e sua disponibilização, um debate aprofundado sobre a conformação constitucional do regime brasileiro de tributação de lucros no exterior perpassa também a consideração de seus efeitos sobre a internacionalização produtiva empresarial, e se (e por que) tais impactos afrontam ou não a Ordem Econômica Constitucional.

Nessa medida, passa-se ao largo de todo o detalhamento histórico das origens da Constituição econômica - que fogem ao objetivo do presente trabalho - destacandose apenas a associação fundamental à ideia de que o sistema econômico per si é dotado de imperfeições (seja qual for o viés ideológico adotado), cabendo ao Estado prever e assegurar um conjunto principiológico de valores que nortearão a prática econômica, a fim de evitar abusos de concorrência e injustiças sociais derivadas de desigualdades econômicas - mais ou menos - aprofundadas. Assim é que a constituição econômica ${ }^{54}$

permanentes em direito tributário internacional. São Paulo: Revista dos Tribunais, 2005.

51 Ib. Ibid.

52 Também é óbvio - por questões de coercitividade e exequibilidade da obrigação jurídica tributária - que não se postula a equiparação da sociedade estrangeira à condição de contribuinte do fisco brasileiro, vis$\grave{a}$-vis o lucro por esta obtido offshore em seu próprio país-sede. Tal fato, aliás, típico exemplo da distinção doutrinária norte-americana entre jurisdiction to prescribe (definição conceitual do espectro de aplicação da lei) e jurisdiction to enforce (núcleo de exequibilidade da lei), estaria naturalmente fora de qualquer possibilidade de renforcement, além de esvaziar de todo sentido e concreção o art. $7^{\circ}$, parágrafo primeiro, do Modelo OCDE. A respeito, cf. XAVIER, Alberto. Direito tributário internacional do Brasil. 7. ed. Rio de Janeiro: Forense, 2008. p. 5 e ss.; MARTHA, Rutsel Silvestre J. The jurisdiction to tax in internacional tax law. Deventer: Boston, 1989. p. 59 e ss.

53 Em igual sentido, por fim, os Comentários da OCDE (parágrafo $11^{\circ}$ dos Comentários ao $\S 1^{\circ}$ do art. $7^{\circ}$ ), ao prescrever que o domicílio da sociedade investidora (sócia) não constitui elemento de conexão internacionalmente aceito como legítima para fundar a tributação do lucro de sociedade estrangeira, por não revelar participação na vida econômica do outro Estado em extensão apta e suficiente a lhe conferir poderes tributários sobre tais lucros. Cf. ORGANIZATION FOR ECONOMIC CO-OPERATION AND DEVELOPMENT (OECD). Model tax convention on income and on capital: condensed version. Paris: OECD Publications, 1998. p. 54-55.

54 José Afonso da Silva conceitua o termo "constituição econômica" como a "parte da Constituição que interpreta o sistema econômico, ou seja: que dá forma ao sistema econômico, que, em essência, é o 
toma corpo e expressão no cenário pós-segunda guerra mundial, quando os modelos liberais clássicos de autorregulação do Estado - já abalados pela crise sistêmica de 1929 sofrem o influxo da miséria e da destruição europeias, sendo superados por modelos mais intervencionistas, capitaneados por John Maynard Keynes.

Desse contraponto entre o resguardo de direitos tipicamente liberais - e a necessidade de garantir uma transformação da realidade social então vigente - é que exsurgem as constituições aspiracionais, dirigentes ou transformadoras, preocupadas não somente com a realidade existente, mas também em firmar um programa para o futuro. ${ }^{55}$ A atual Constituição Federal de 1988 seria um típico exemplo dessa tentativa de harmonização, de pretensões claramente programáticas, as quais, em relação à Ordem Constitucional Econômica, compreenderiam um conjunto principiológico em sentido estrito e em sentido amplo. ${ }^{56}$

Em sentido amplo, trata-se do conjunto de mandamentos esparsos contidos no texto magno, não necessariamente sistematizados no capítulo que cuida da "Ordem Econômica e Financeira", a exemplo do desenvolvimento nacional, alçado a "objetivo fundamental da República Federativa do Brasil" (art. 3, CF); em sentido estrito, a tutela da ordem econômica pressupõe atendimento a dados princípios otimizadores, expressamente elencados no art. 170, incisos, $\mathrm{CF}^{57}$

Tomadas essas premissas, o desenho da ordem econômica - ferramenta à consecução dos ideais descritos - introjeta o valor “desenvolvimento" como norte a ser seguido e implementado também nas atividades estatais de fiscalização, incentivo e planejamento econômico estatal, quando ao Estado incumbir atuar na qualidade de agente normativo e regulador da atividade econômica, nos termos do art. 174, CF. Assim é que a Constituição procuraria definir as balizas institucionais de um projeto nacional de desenvolvimento, cabendo aos formuladores de políticas públicas implementá-las na prática, em consideração ao contexto ideológico definido pelo próprio texto, ${ }^{58}$ estimulando

capitalista”. Cf. SILVA, José Afonso da. Curso de direito constitucional positivo. São Paulo: Malheiros, 2010. p. 791.

55 Cf. BERCOVICI, Gilberto. Constituição econômica e desenvolvimento: uma leitura a partir da Constituição de 1988. São Paulo: Malheiros, 2005. p. 31-35.

56 Cf. TAVARES, André Ramos. Direito constitucional econômico. São Paulo: Método, 2006. p. 125-128.

57 São eles: I - soberania nacional; II - propriedade privada; III - função social da propriedade; IV - livre concorrência; V - defesa do consumidor; VI - defesa do meio ambiente, inclusive mediante tratamento diferenciado conforme o impacto ambiental dos produtos e serviços e de seus processos de elaboração e prestação; VII - redução das desigualdades regionais e sociais; VIII - busca do pleno emprego; IX tratamento favorecido para as empresas de pequeno porte constituídas sob as leis brasileiras e que tenham sua sede e administração no País.

58 BERCOVICI, Gilberto. Constituição econômica e desenvolvimento ... cit., p. 69-71. 
atividades econômicas de interesse nacional, orientadoras ao setor privado e determinantes ao setor público, sob pena de desrespeito à própria ordem econômica. ${ }^{59}$

Nessa medida, a doutrina diverge quanto à própria natureza do preceito insculpido no art. $3^{\circ}$, inciso II, da Constituição Federal: seria norma programática - de aplicabilidade prospectiva - ou teria densidade normativa maior?

Dimoulis e Vieira atribuem-na dois sentidos distintos e paralelos: em primeiro lugar, como norte ideológico à aplicação do ordenamento constitucional e infraconstitucional; segundo, enquanto mandamento ao legislador na elaboração de programas políticos, prevendo objetivos práticos/concretos desse primado abstrato, sob pena de responsabilização jurídico-política. ${ }^{60}$

Feitas as considerações introdutórias, cumpre perquirir: em que medida $o$ sistema brasileiro de tributação em bases universais - com regra de antidiferimento ampla - está ou não em acordo com as políticas públicas favoráveis ao desenvolvimento do país, e no limite, conforme a Constituição? Ou ainda, em outros termos, haveria limites condicionantes a serem observados pelo Estado, na criação de uma política industrial de internacionalização produtiva?

Em síntese, muito embora a definição de tais aspectos seja tarefa essencialmente de economistas e administradores, é razoável estabelecer que uma política de internacionalização pautada em critérios objetivos postos pela Administração pode potencialmente contribuir ao desenvolvimento nacional. $\mathrm{O}$ modus por que processada, ou ainda, quais seriam esses termos e condicionantes, é que delimitará em que hipóteses o fenômeno será desejado - pela geração de externalidades positivas, como o incremento de renda, empregos indiretos e redistribuição de riquezas - ou refutado - à conta de perdas arrecadatórias significativas, bem como reduções da balança comercial, desemprego setorial, etc. Tal modo de atuação será refletido nas políticas de incentivo/desincentivo à internacionalização, tendo por baliza o ponto ótimo de equilíbrio à consecução dos interesses nacionais - desenvolvimento em sentido lato.

Problema fundamental a ser destacado na sistemática brasileira de tributação de lucros offshore, à luz da Ordem Econômica Constitucional, é sua aplicabilidade indiscriminada, sempre que envolvida uma empresa de capital nacional internacionalizada

59 Uma leitura nesses moldes do capítulo da ordem econômica constitucional permite extrair o axioma fundamental ao presente trabalho - de que uma política pública, seja econômica, industrial, agrícola ou mesmo [e principalmente] fiscal - que não favoreça o desenvolvimento nacional será per si inconstitucional.

${ }^{60}$ Também aqui é curial compreender qual a extensão do termo "desenvolvimento": a própria Constituição Federal não o teria restringido à acepção econômica, à medida que assegura uma série de direitos de diversas naturezas distintas (civis, sociais, culturais, entre outras). Cf. DIMOULIS, Dimitri; VIEIRA, Oscar Vilhena. Constituição e desenvolvimento. In: RODRIGUEZ, José Rodrigo (Coord.). Fragmentos para um dicionário crítico de direito e desenvolvimento. São Paulo: Saraiva, 2011. p. 56. 
controlada - mesmo nas hipóteses em que o investimento deveria ser claramente incentivado, porquanto eminentemente produtivo e benéfico à geração de externalidades positivas ao país. ${ }^{61} \mathrm{O}$ problema, nessa esteira, é justamente o espectro de incidência tributária, incapaz de discernir quando o investimento é favorável ao desenvolvimento - i.e., constitucional - e quando não. Tal inconstitucionalidade, em princípio, poderia ser contornada pelo redirecionamento da incidência do regime às hipóteses de abuso de posição ou operação internacional, ensejando ipso facto uma postura rígida da jurisdição fiscal brasileira. ${ }^{62}$ Da maneira como atualmente concebido, a partir da Lei n. 12.793/2014, não parece possível, em princípio, defender uma regra antidiferimento a tal ponto ampla que não possa distinguir as operações de internacionalização produtiva de controladas desejáveis das controladas não desejáveis. ${ }^{63}$

Nessa perspectiva, um juízo de conformação à ordem econômica constitucional deve sempre ser considerado - como critério balizador suplementar na formulação de políticas públicas que impactem, direta ou indiretamente, o sistema tributário nacional e a competitividade das empresas brasileiras em mercados cada vez mais globalizados. Tal harmonização pressupõe, em última instância, que as políticas econômicas adotadas pela Administração tenham diretrizes tão claras quanto possíveis, enquanto subconcretizações do princípio diretivo do desenvolvimento do país. Muito embora essa perspectiva de estudo não desloque o conflito acirrado de interesses contrapostos - a um lado, contribuintes preocupados com os efeitos aparentemente deletérios da arrecadação sobre seus negócios, e a outro, a administração, orientada à proteção arrecadatória e a efetividade do sistema tributário - esse enfoque permitiria uma salutar oxigenação de argumentos e ponderações para ambos os lados, especialmente pela própria indefinição de marcos legislativos claros - nos tribunais superiores.

A par da trajetória da evolução normativa brasileira da sistemática $C F C$ rules, duas são as razões primaciais motivadoras da adoção do worldwide income principle seguido de regra antidiferimento: (i) a nova macroeconomia brasileira, pósinflação e pós-Real; (ii) as diretivas da OCDE e a pressão internacional à adoção de

${ }_{61}$ Nessa hipótese, a inconstitucionalidade prefigura-se evidente e incontornável.

${ }^{62}$ São exemplos nesse sentido a constituição de filiais, sucursais, coligadas ou controladas em tax havens ou regimes fiscais privilegiados, com o intento preponderante ou único de diferir/reduzir o fato imponível no país de residência (via de regra associada a elementos redituais passivos, cuja volatilidade é tendencialmente maior).

63 Não se trata aqui de predizer com absoluta precisão qual o melhor conceito ou o melhor regime de tributação antidiferimento, dentre os vários existentes (ou mesmo prescrever um novo modelo, de lege ferenda): com efeito, a discussão não está centrada em casos border line, em que paire dúvida sobre a contribuição ou não ao desenvolvimento nacional; ao revés, pode-se definir com absoluta certeza determinados investimentos cuja contribuição ao país é evidente per si, e que, não obstante, sofrerão o desincentivo indireto do regime brasileiro de tributação offshore, o que denuncia a inconstitucionalidade incontornável do regime, nos moldes como se encerra atualmente. 
um regime fiscal transparency como forma de resguardo dos escopos arrecadatórios estatais vis-à-vis planejamentos tributários escusos. Não obstante, a normação brasileira destoa abruptamente das práticas transnacionais e do modelo recomendado pela OCDE, dada a regra anti-deferral de viés praticamente absoluto, apenas parcialmente capaz de discriminar a natureza de investimentos realizados por entidades investidas controladas. É esse o motivo, ademais, que nos leva a sustentar a inconstitucionalidade do desenho normativo brasileiro, porquanto, ressalvadas hipóteses borderline, em que a identificação dos desígnios do investimento do sujeito passivo seja de difícil aferição, há também hipóteses e casos claros e evidentes em que a natureza dos investimentos é produtiva sem qualquer dúvida. Assim é que sustentar a pertinência legal e constitucional de tal regramento fere, sob a ótica de um constitucionalismo econômico, o princípio e valor positivado de desenvolvimento econômico e social balizador da atuação do poder público na elaboração de políticas governamentais.

Consectário do raciocínio, a norma brasileira desvirtua-se de seu sentidoraiz, isto é, a natureza antielisiva, à medida que não coíbe somente práticas abusivas de elisão fiscal internacional, mas também investimentos e realocações de recursos produtivos e benéficos aos países envolvidos. Não se deve descurar, dentro do cenário brasileiro, que o objetivo da sistemática de tributação de lucros offshore não teve em mente tão só a dissuasão de planejamentos abusivos, mas a ampliação (tão generosa quanto possível) do orçamento federal, a fim de prover lastro à concreção de políticas públicas então idealizadas.

As controvérsias doutrinárias sobre a indefinição de balizas legais seguras - também refletidas no âmbito jurisprudencial - geram em seu bojo um só resultado: insegurança jurídica, com expressivos custos econômicos e sociais de ordem prática. Primeiro, da parte das empresas, no tocante às inúmeras despesas processuais com o ajuizamento de demandas para contestar as exações fiscais (honorários advocatícios, taxas forenses e burocráticas, contingenciamentos para prováveis perdas em balanços patrimoniais, depósitos compulsórios, custo em tempo e recursos, ${ }^{64}$ etc.); segundo, as perdas sofridas pela Administração Pública com a incerteza arrecadatória em face de montantes objeto de questionamento judicial, e com os gastos burocráticos na defesa da legitimidade das exações (procuradores e o respectivo aparato técnico e instrumental). Trata-se, em conjunto, de um (grande) volume de recursos e tempo despendidos

64 Sem prejuízo do exposto, acrescem à soma de recursos despendidos por ocasião do novo diploma as despesas referentes à escrituração contábil da apuração individualizada de ativos e passivos sujeitos a ajuste de avaliação patrimonial, a fim de demonstrar nos pormenores a correspectiva realização pela investidora em balanço consolidado. 
com aplicações inócuas, cuja destinação poderia alavancar uma série de benefícios socioeconômicos: geração de renda, infraestrutura, entre outros.

Em termos econômicos, portanto, o custo de oportunidade do direcionamento de todo esse plexo de recursos, de um lado, ao ataque e questionamento da legalidade das medidas, e de outro, à defesa de sua legitimação e validade jurídica, prefigura-se extremamente alto e desproporcional, reflexo muitas vezes da indefinição de balizas seguras na sistemática brasileira de tributação de lucros offshore.

Tamanha é a controvérsia em torno das questões suscitadas que o próprio Supremo Tribunal Federal demonstra insegurança para dirimi-las. A cisão da Corte no julgamento paradigmático da ADI n. 2.588-1/DF é exemplo claro disto, ao delimitar apenas um espectro mínimo de aplicabilidade das CFC rules (notadamente, os pontos mais extremados e aparentemente fáceis de resolver). As demais circunstâncias (justamente aquelas borderline, em que repousam dúvidas sobre a produtividade ou não do emprego dos recursos) não foram objeto de resolução majoritária pela Corte Suprema.

Além disso, não só o STF, mas os Tribunais em geral, nas respectivas competências que lhe são pertinentes, não cuidaram de deslindar satisfatoriamente as questões jurídicas exsurgidas do regime brasileiro de tributação de lucros offshore até o momento. À controvérsia jurídica de estabelecer a natureza jurídica do instituto (com o subsequente deslocamento e reporte ao regime jurídico respectivo que lhe é peculiar) assomam as dificuldades extrajurídicas, i.e., as pressões políticas e sociais de setores da Administração e dos contribuintes (que abrangem, v.g., as dez maiores empresas nacionais de capital aberto), ambos expostos a um passivo contencioso bilionário ( $\mathrm{R} \$ 134,4$ bi) e aos efeitos econômicos daí advindos. Daí porque um debate estritamente jurídico, descontextualizado do entorno político e econômico que lhe subjaz, subdimensiona o problema (e sua direta repercussão na vida prática das empresas).

À luz do exposto, são dois os objetivos fundamentais a priori contraditórios entre si. De um lado, em um mundo ideal, cada caso concreto deveria ser conhecido em suas minúcias, aferindo se houve ou não exercício abusivo do poder de controle, isto dentro de um procedimento que resguarde ao contribuinte o amplo direito de justificar suas condutas e propósitos, corolário do due process of law e da ampla defesa, de tutela constitucional. Nada obstante, razões de comodidade e praticidade arrecadatória desenham os contornos de uma norma $C F C$, com o claro objetivo de aumentar a arrecadação sob o predicado da igualdade entre os contribuintes em igual situação.

Entrevisto o choque, primeiro ponto de reflexão é a inadmissibilidade - sob a ratio de simplificação tributária e/ou insuficiência da administração fazendária em fiscalizar - da criação de uma presunção absoluta (iuris et de iure) de que todos os controladores brasileiros adquirem disponibilidade jurídica/econômica sobre suas investidas controladas 
(ou equiparadas) em 31 de dezembro, como se todos preconcebidamente se utilizassem de tais participações com a única finalidade escusa de economia de tributos.

Fato é que a re/desqualificação de um negócio jurídico de direito privado, sempre que demonstrada sua abusividade ou finalidade única de economia tributária, é direito inconteste da Administração Pública. Corolário disso, tal conduta demanda um procedimento legal que confira ao sujeito passivo a mais ampla defesa e o direito à contraprova, podendo-se por esta tensão dialética afastar ou não a presunção legal préfixada.

Daí porque, a nosso ver, a ilação mais adequada pende à interpretação do art. $43, \S 2^{\circ}$, do CTN como autorização legislativa à fixação de uma presunção sempre relativa, passível de desconstrução pela produção de provas de ambos os interessados. A presunção, nesse sentido, apenas significa uma grande probabilidade de caracterizarse como disponíveis dados rendimentos de controladas (e entidades a elas equiparadas), sempre que evidenciadas determinadas condições pré-definidas em lei. Nada impediria ao contribuinte, porém, legitimamente infirmar esse pressuposto, demonstrando a licitude e conformidade de sua conduta na consecução de suas atividades empresariais.

Sem embargo do exposto, também é fato que a legislação draconiana brasileira não trouxe expressivo incremento na arrecadação tributária. ${ }^{65} \mathrm{~A}$ isso soma-se o clima de incerteza e insegurança jurisprudencial - que conquanto não decisivo per si, impacta na tomada de decisão do empresário sobre como e onde investir.

Isto posto, resta ainda pendente a conformação constitucional do novo regime de tributação brasileiro de lucros gestados offshore, considerando-se, dentre outros interesses e escopos: (i) a atenuação do espectro de incidência e a excessiva oneração de investimentos produtivos de empresas brasileiras no exterior; (ii) não prejudicar a fiscalização e arrecadação de tributos necessários ao custeio da máquina pública; (iii) harmonizar as prescrições normativas em espécie com os tratados e convenções internacionais em matéria de tributação, ratificados pelo Brasil, evitando querelas

${ }_{65}$ O dilema da Administração pública federal brasileira é autoexplicativo: no exercício de 2011, por exemplo, a meta fiscal só foi atingida graças ao aumento de $12,1 \%$ da receita de tributos no mesmo período e mediante novo recorde de arrecadação da Receita Federal, de 23,5\% do Produto Interno Bruto brasileiro. Em outros termos, o lastro ao cumprimento de nossas metas fiscais continua assentado na perigosa premissa de que as bases arrecadatórias estarão ad eternum em curva ascendente. Como bem coloca Eurico Marcos Diniz de Santi, a pergunta central dessa política será averiguar qual a natureza desses "recordes", e qual seu custo institucional. Cf. SANTI, Eurico Marcos Diniz de. Tributação dos lucros de controladas e coligadas no exterior: legalidade precária proposta por regulamentação provisória via MP reeditada 35 vezes (há mais de 10 anos), problema sistêmico que se confirma no placar de 5x5 no STF e nas decisões do STJ, expondo limites e conflitos entre direito e economia, e mobilizado pelo contencioso bilionário entre o Estado e as 10 maiores empresas brasileiras de capital aberto. Disponível em: <http://www.fiscosoft.com.br/a/5omh/ tributacao-dos-lucros-de-controladas-e-coligadas-no-exterior-eurico-marcos-diniz-de-santi>. Acesso em: 12 jul. 2013. 
diplomáticas com os respectivos países signatários; (iv) garantir igualdade de tratamento entre o investimento doméstico e aquele feito no exterior.

Seja qual for a ótica e posicionamento adotados, a principal medida preconizada é (ou deve ser) o primado da segurança jurídica aos jurisdicionados, favorecendo não só a internacionalização de capitais dentro dos standards ótimos à conjuntura brasileira, mas viabilizando a livre circulação de capitais e o fomento ao desenvolvimento econômico e social, princípios insculpidos no texto constitucional.

Bordeaux, le 17 avril 2016.

\section{Referências}

AMIN, Samir. Transforming the world economy: nine critical essays on the new international economic order. Kent: United Nations University \& Hodder and Stoughton, 1984.

BARRETO, Fernando Mello; RICUPERO, Rubens. A importância do investimento direto estrangeiro do Brasil no exterior para o desenvolvimento socioeconômico do país. In: ALMEIDA, André. (Coord.). Internacionalização de empresas brasileiras: perspectivas e riscos. Rio de Janeiro: Elsevier, 2007.

BERCOVICI, Gilberto. Constituição econômica e desenvolvimento: uma leitura a partir da Constituição de 1988. São Paulo: Malheiros, 2005.

BIFANO, Elidie Palma. A tributação no setor comercial: panorama da carga tributária nas operações de comércio. In: SANTI, Eurico Marcos Diniz de (Coord.). Curso de direito tributário e finanças públicas: do fato à norma, da realidade ao conceito jurídico. São Paulo: Saraiva, 2008.

BOBBIO, Norberto. Contribución a la teoria del derecho. São Paulo: Livraria dos Advogados, 1981.

. A função promocional do direito. In: BOBBIO, Norberto. Da estrutura à função: novos estudos de teoria do direito. Barueri: Manole, 2007.

CALIENDO, Paulo. Estabelecimentos permanentes em direito tributário internacional. São Paulo: Revista dos Tribunais, 2005.

CARVALHO, Cassius Vinicius; BIFANO, Elidie Palma. Anotações sobre a tributação internacional da renda. In: SANTI, Eurico Marcos Diniz et al. (Coord.). Tributação internacional e dos mercados financeiro e de capitais. São Paulo: Quartier Latin, 2005.

CASELLA, Paulo B. União Européia - instituições e ordenamento jurídico. 5. ed. São Paulo: LTr, 2002. 
DIMOULIS, Dimitri; VIEIRA, Oscar Vilhena. Constituição e desenvolvimento. In: RODRIGUEZ, José Rodrigo (Coord.). Fragmentos para um dicionário crítico de direito e desenvolvimento. São Paulo: Saraiva, 2011.

GRUPENMACHER, Betina Treiger. Tratados internacionais em matéria tributária e ordem interna. São Paulo: Dialética, 1999.

MACIEL, Taísa. Tributação dos lucros das controladas e coligadas estrangeiras. In: TÔRRES, Heleno Taveira (Coord.). Direito tributário internacional aplicado. São Paulo: Quartier Latin, 2005. v. 3 .

MARTHA, Rutsel Silvestre J. The jurisdiction to tax in internacional tax law. Deventer: Boston, 1989.

MERLE, Marcel. Sociología de las relaciones internacionales. Trad. Mesa Garrido. 2. ed. Madrid: Alianza Universidad, 1980.

NEVES, Marcelo. Entre Têmis e Leviatã: uma relação difícil. O estado democrático de direito a partir e além de Luhmann e Habermas. São Paulo: Martins Fontes, 2006.

ORGANIZATION FOR ECONOMIC CO-OPERATION AND DEVELOPMENT (OECD). Model tax convention on income and on capital: condensed version. Paris: OECD Publications, 1998.

ORGANIZATION FOR ECONOMIC CO-OPERATION AND DEVELOPMENT (OECD). Harmful tax competition: an Emerging Global Issue. Paris: OECD Publications, 1998.

PADIAL, Ignacio Cruz. Transparencia fiscal internacional: régimen general y interrelación con los convênios de doble imposición. Valencia: Tirant lo Blanch, 2000. v. 13.

PEREIRA, Roberto Codorniz L. O regime especial de tributação de lucros auferidos no exterior. São Paulo: NEF - Núcleo de Estudos Fiscais da Escola de Direito de São Paulo da Fundação Getúlio Vargas, 2011.

ROSEMBUJ, Tulio. Derecho fiscal internacional. Barcelona: El Fisco, 2001.

SCHOUERI, Luís Eduardo. Tratados e convenções internacionais sobre tributação. Direito Tributário Atual, São Paulo, v. 17, p. 20-49, 2003.

SILVA, José Afonso da. Curso de direito constitucional positivo. São Paulo: Malheiros, 2010.

TAVARES, André Ramos. Direito constitucional econômico. São Paulo: Método, 2006.

TÔRRES, Heleno Taveira. Lucros auferidos por meio de controladas e coligadas no exterior. In: TÔRRES, Heleno Taveira (Coord.). Direito tributário internacional aplicado. São Paulo: Quartier Latin, 2005. v. 3.

XAVIER, Alberto. Direito tributário internacional do Brasil. 7. ed. Rio de Janeiro: Forense, 2008. 


\section{Internet}

DANIEL NETO, Carlos Augusto. Disponibilidade econômica e jurídica: breves colocações. Disponível em: <http://jusblogdodaniel.blogspot.com>. Acesso em: 4 abr. 2013.

ERNST \& YOUNG. Global Tax alert report (News from America Tax Center). In: Brazil enacts tax reform. Disponível em: <http://www.ey.com/GL/en/Services/Tax/International-Tax/Alert--Brazilenacts-tax-reform>. Acesso em: 20 fev. 2015.

FEDERAÇÃO DAS INDÚSTRIAS DO ESTADO DE SÃO PAULO (FIESP). Disponível em: $<$ http://www.fiesp.com.br/irs/coscex/pdf/transparencias_reuniao_coscex_20_03_12_luis_afonso_ lima_sobeet.pdf $>$. Acesso em: 2 abr. 2012.

FUNDAÇÃO INSTITUTO BRASILEIRO DE GEOGRAFIA E ESTATÍSTICA(IBGE). Disponível em: <http://www.ibge.gov.br>. Acesso em 21 ago. 2012.

GERMANO, Livia de Carli; BORGES, Alexandre Siciliano. ADIn 2588: acabou mesmo a discussão para "coligadas" fora de "paraíso fiscal”? Disponível em: $<$ http://www.migalhas.com.br/ dePeso/16,MI180512,21048-ADIn+2588+acabou+mesmo+a+discussao+para + coligadas + fora + de +paraiso>. Acesso em: 20 abr. 2015.

LOTT, Maíra Carvalhaes. Tributação dos lucros no exterior: um contributo para o ordenamento jurídico brasileiro face à perspectiva do direito fiscal internacional e a práxis do direito fiscal europeu. Disponível em: <http://www.fiscosoft.com.br/a/6098/tributacao-dos-lucros-no-exteriorum-contributo-para-o-ordenamento-juridico-brasileiro-face-a-perspectiva-do-direito-fiscalinternacional-e-a-praxis-do-direito-fiscal-europeu-maira-carvalhaes-lott>. Acesso em: 25 fev. 2013.

MULTINACIONAIS do Brasil voltarão a investir no exterior. Revista Exame Online, 7 fev. 2012. Disponível em: <http:/exame.abril.com.br/negocios/empresas/noticias/multinacionais-do-brasilvoltarao-a-investir-no-exterior-3>. Acesso em: 3 abr. 2013.

NEDER, Marcos. O impasse dos tratados na tributação de lucros de controladas no exterior. Disponível em: <http://jota.info/o-impasse-dos-tratados-na-tributacao-de-lucros-de-controladasno-exterior>. Acesso em: 20 abr. 2015.

PINTO, Gustavo Mathias Alves. Tratados internacionais em matéria tributária e sua relação com o direito interno no Brasil. Revista Direito GV, São Paulo, v. 4, n. 1, jun. 2008. Disponível em: $<$ http://www.scielo.br/scielo.phpscript=sci_arttext\&pid=S180824322008000100007\&lng=en\&nr m=iso $>$. Acesso em: 14 abr. 2013.

SALGADO SOARES, Emília. Externalidades negativas e seus impactos no mercado. Dissertação (Mestrado) - Fundação Getúlio Vargas. Disponível em: <www.bibliotecadigital.fgv.br>. Acesso em: 6 nov. 2013. 
SANTI, Eurico Marcos Diniz de. Tributação dos lucros de controladas e coligadas no exterior: legalidade precária proposta por regulamentação provisória via MP reeditada 35 vezes (há mais de 10 anos), problema sistêmico que se confirma no placar de 5x5 no STF e nas decisões do STJ, expondo limites e conflitos entre direito e economia, e mobilizado pelo contencioso bilionário entre o Estado e as 10 maiores empresas brasileiras de capital aberto. Disponível em: $<$ http://www. fiscosoft.com.br/a/5omh/tributacao-dos-lucros-de-controladas-e-coligadas-no-exterior-euricomarcos-diniz-de-santi>. Acesso em: 12 jul. 2013.

XAVIER, Alberto. Equívocos e sofismas em matéria de lucros no exterior. Disponível em: <http:// www.editorajc.com.br/2012/03/equivocos-e-sofismas-em-materia-de-lucros-no-exterior/>. Acesso em: 14 abr. 2015. 
